\title{
THE CONTROL OF PATENT RIGHTS RESULTING FROM FEDERAL RESEARCH
}

\section{David LIOYd KreEger*}

A golden stream of patentable inventions pours from the scientific research and development conducted or financed by the Federal Government. Some of the discoveries resulting from these activities pass under Government ownership or control, equivalent in current practice to public dedication of the particular device or process. The greater part of these technological riches, however, embodied in patents and patent applications, flows into the coffers of private industry, subject only to a nonexclusive license in the Government, and is available for commercial use, exploitation, or suppression according to the interests of the owner.

The question of what disposition of patent rights from Federal research will best serve the public interest is one that has been pondered and mooted in all branches of Government during the past fifty years, ${ }^{1}$ the numerous studies having culminated in an exhaustive investigation recently completed by the Department of Justice. ${ }^{2}$ On the basis of that study, the Attorney General submitted a comprehensive report to the President in May, x947, recommending that as a basic policy all technology financed with Federal funds should be owned or controlled by the Government. ${ }^{3}$

The formulation of a sound policy for publicly financed inventions acquires special urgency from the dominant role assumed by the Federal Government during the last decade in the field of scientific inquiry. Before World War II, private industry financed about two-thirds of the Nation's research, estimated to involve some $\$ 300,000,000$ in 1938 , with Government and institutional research accounting for about $\$ 50,000,000$ each. But within six years the positions were reversed, and by July I, I944, the Government was financing more than three-fourths of all research in this country, spending over $\$ 900,000,000-$-including $\$ 200,000,000$ for research in the field of atomic energy-and utilizing the services of at least 20,000 Government

* A.B. 1929, Rutgers University; LL.B. 1932, Harvard University. Member of the District of Columbia bar. Member of Board of Editors of Harvard Law Revew, I930-1932; Special Assistant to the United States Attorney General and Chief of Supreme Court Section, Claims Division, United States Department of Justice, r942-1946. Editor of the Attorney General's R'EPORT AND RECOMMENDATnONS Concerning the Government's Patent Practices and Policies (1947).

${ }^{2}$ U. S. Dep't Justice, Report and Recommendattons of the Attorney *General to tife Prestdent, Investigation of Government Patent Practices and Policies 163-314 (1947) (hereinafter cited as REP. ATr'Y GEN.) summarizes all the prior studies in the field since the turn of the century.

2 I REP. ATT'y GEN. 1, ro-r2.

I id. at $2-8$. 
scientists and technicians, and more than 15,000 other civilian employees. ${ }^{4}$ Moreover, the indications are that the Government will continue to account for the lion's share of research in the post-war period. The Federal research budget for the fiscal year ending June 30 , I947, was again $\$ 700,000,000$, exclusive of the amount allotted to atomic energy research, ${ }^{5}$ and a proposed long-term program of Federal aid to scientific research received nearly unanimous endorsement in 1945 and $19466^{6}$ Indeed, the solution of many important technological problems currently confronting our civilization requires the pooling of facilities on a vast scale, involving expenditures which the Federal treasury is better suited to finance than private enterprise, particularly in the field of basic research where the profit return is highly conjectural. ${ }^{\top}$

\section{The Governament as Patent Owner}

The United States may acquire and exercise patent rights in the same way as any private corporation. The arid controversy as to whether acquisition of a patent by the Government would "merge" and extinguish the rights ${ }^{8}$ is rendered academic by the decisions which expressly or inferentially recognize the power of the Federal Government to receive a patent assignment, ${ }^{9}$ the several acts of Congress authorizing the acquisition and licensing of patents by the Government in specified circumstances, ${ }^{10}$ and the well established administrative practice of licensing Federally

-U. S. Nat. Resources Comaittee, Research-A Nattonal. Resource, Pt. 1, 72-74 (1938); Pt. 2 , 19-39 (1940); The Government's Wartime Research and Development, 1940-44, Report No. 5 of the Subcommitee on War Mobilization to Senate Committer on Military Affairs, Pt. I, 79th Cong., Ist Sess. vii, 278-326 and passim (1945); Pt. 2, 3-8 (1945); Industrial Research and Cenavging Technology, W. P. A. Nat. Research Project (Jan. I940).

"92 Cong. Rec. 8265 (July 2, 1946); Bureau of Budget, Tabulatton of Funds Avallable for Research and Developarent for Fiscal Year 1947 (Oct. 24, I946).

- President Truman's Message to Congress, Sept. 6, 1945, H. R. Doc. No. 282, 79th Cong., Ist Sess. 20-2I (1945); Hearings before the Subcommittee on War Mobilization of Senate Committee on Military Affairs on S. 1297 and related bills, 79th Cong., 2d Sess. (1946); SEN. REp. No. 1136, 79th Cong., 2d Sess. (1946); 92 Cong. Ricc. 8146 ff. (I946); Hearings before the Subcommittee of House Committee on Interstate and Foreign Commerce on $H . R .6448$, 79th Cong.. 2d Sess. (1946); Shapley, Status Quo or Pioneer, rgr Harpers 314 ff. (Oct. 1945).

'See The Great Science Debate, Fortune, June, 1946, p. I16.

${ }^{8}$ Ewing, Government Owned Patents, Io J. PAT. OFF. Soc'y I49 (I928), and Wille, Government Ownership of Patents, I2 FORD. L. REv. I05 (I943), suggest that no enforceable patent rights would Icmain in the Government because of a kind of "merger"; a contrary view is rypressed by Kwai, Patents to Government Employees, I3 J. PAT. OFF. Soc'Y 387 (193I); Broder, Government Otuncrship of Patents, 18 id. at 697 (1936); and Nat. Pat. Planning Comm'n, Government Otined Patents and Inventions of Government Employees and Contractors 9 (Second Report, -y44). Compare also Herbert A. Howeli, Copyright LAw 40 n. (I942).

${ }^{\circ}$ United States v. Dubilier Condenser Corp., 289 U. S. $178,193,206$ (I933); Solomons v. United States, 137 U. S. 342,346 (189o); Houghton v. United States, 23 F. 2 d 386 , 390-39I (C. C. A. 4 th 1928), cert. denied, 277 U. S. 592 (1928); cf. James v. Campbell, 104 U. S. 356, 358 (1881). A statement to the contrary in the majority opinion in United States v. Dubilier Condenser Corp., supra, was deleted on motion of the Solicitor General, 289 U. S. 706. See also the uniform rulings of the Attorney General that the Government may receive an assignment of patents from its employees: 37 OPs. ATT'Y GEN. 180, 185 (1933); 31 id. 463 (1919); 32 id. 321 (1920); 34 id. 320 (1924); 37 id. 180 (1933); 38 id. 425 , 534 (1936); 39 id. 164 (1938).

${ }^{10}$ Synthetic Liquid Fuels Act of 1944, 58 STAr. I9I (1944), 30 U. S. C. $\$ 323$ (Supp. 1946); Tennessee Valley Act of I933, 48 STAT. 61 (I933), I6 U. S. C. \$83Id (i) (1940); Fortifications Appropriation Act of July 6, 3916, 39 Stat. 348, amending Rev. Star. $\$ 4894$ (1875), 35 U. S. C. $\$ 37$ (1940); Joint Resolution of June 3, 1864,13 Stat. 588; Act of June 19, 1878, 20 Stat. 583 . 
owned patents. ${ }^{11}$ According to a line of rulings by the Attorney General going back almost thirty years, the several Federal departments and agencies, even without express statutory authorization, may issue revocable, nontransferable, and nonexclusive licenses, with or without royalty. ${ }^{12}$ And as a practical matter, the Government may open its inventions to the public at will, either by publishing them without seeking a patent, ${ }^{13}$ or by issuing a free license to anyone who desires it. $^{14}$

II

\section{The Inventions of Federal Employees}

\section{A. Applicable Legal Principles}

Under general principles of law, an employer may acquire an interest in the inventions made by his employee within the scope of employment, ranging from a free nonexclusive license to full ownership of the patent rights, and the United States as an employer is entitled to these prerogatives of the employment relationship. ${ }^{15}$ Hence, as employer, the Government is entitled to equitable ownership of an invention made by a Federal employee within the scope of his employment if he was engaged or assigned to accomplish that result, ${ }^{16}$ or, to state the criterion in the

${ }^{11}$ See Hearings before House Patents Committee on H. R. 12412, 69th Cong., 1st Sess. I (1926); Report of Interdepartmental Patents Bonrd, Sen. Doc. No. 83, 68th Cong, ist Sess. I (1923); Hearings before Senate Patents Committee on S. 2303 and S. 2491, 77th Cong., 2d Scss. 1208 ff. (1942); Wille, loc. cit. supra, note 8 , at no6.

${ }_{12}{ }_{3} 8$ Ops. ATT'Y GeN. 425, 427, 534 (1936); 34 id. 320, 328, 329 (1924); 31 id. 463, 466 (1919); 39 id. 164 (1938); 37 id. 180 (1933). Congressional sanction is, however, necessary for an exclusive or irrevocable license or an outright assignment of a patent. $3 x^{i d} .463$ (xg19); 34 id. 320 (1924); 38 id. 534 (1936). The Surplus Property Act of 1944, 58 Stat. 765, 774, 775 (r944), 50 U. S. C. App. $5 \$ 1628$ (a), I629, authorizes the sale of "surplus" patents and inventions, and the Trading with the Enemy Act, 40 STAT. 4II (I917), as amended, 50 U. S. C. App. \$\$5, 6, 616 (Supp. I946), authorized the sale of patent rights seized by the Alien Property Custodian during World War I. See United States v. Chemical Foundation, 272 U. S. I (I926).

${ }^{13}$ No patent can issue on an invention published more than one year prior to filing a patent application thereon. Rev. STAT. $\$ 4886$ ( 1875 ), 35 U. S. C. \$3I (1940).

${ }^{14}$ While the Attorney General has denied the power of the executive to issue irrevocable licenses without statutory authorization, see note 12, stipra, public dedication of Government-owned patents has ibeen practiced by several departments and agencies for many years. See 2 Rep. ATr'Y GEN. 25 (Dcpartment of Agriculture); 2 id. 83, 106 (Bureau of Standards); 2 id. 199-200 (Interior Department); 2 id. 479, 483 (War Department); 2 id. 3II-3I2 (Navy Department). The Synthetic Liquid Fucls Act .of 1944, supra, note 1o, expressly authorizes public dedication of a certain class of Government-owned :inventions. A public register of Government-owned patent rights is now maintained in the Patent 'Ofice pursuant to Exec. Order No. 9424, 9 FED. REG. 1959 (1944).

${ }^{15}$ Solomons v. United States, supra, note 9, at 342; United States v. Burns, 12 Wall. 246,252 (1870); Gill v. United States, 160 U. S. 426, 435 (1896); United States v. Dubilier Condenser Corp., supra, note 9, at I92; Houghton v. United States, supra, note 9, at 388; Shearer v. United States, 87 Ct. Cl. 40, 79 (1938). Compare the dissenting opinion of Justice Stone in the Dubilier case, supra, at 217-218, suggesting that Government service may create equities in the employer which are absent from private employment.

${ }^{20}$ Solomons v. United States, supra, note 9, cited and followed in Gill v. United States, supra, note I5, at 432, 435 (a case involving Government employment), and Standard Parts v. Peck, 264 U. S. 52 (Ig24) (private employment). In a similar case, the Supreme Court stated, obiter, that the Government would be entitled to ownership of an invention made by an employee who was "specially employed to make experiments with a view to suggest improvements." United States v. Burns, stipra note 15. Compare McAleer v. United States, 150 U. S. 424, 430 (1893). Hapgood v. Hewitt, IIg U. S. 226 (1886), and Dalzell v. Dueber Mfg. Co., 149 U. S. 315 (1893), held that a private employer was cntitled to the invention only if there was an express agreement to that effect, but the scope of these decisions was limited by the Dubilier case, supra, note 9, at 187 , which cited them for the proposition that the employer is not entitled to inventions made in the course of general employment. 
language of the most recent case, if his duties "contemplated invention" of that general type. ${ }^{17}$

This rule has been criticized as too "mechanical" by the late Chief Justice (then Associate Justice) Stone, who suggested that the governing principle should be "whether the employee may in equity and good conscience, retain the benefits of the patent," taking into account the public interest in the functions from which the inventions were evolved. ${ }^{18}$

The rule that the employer becomes entitled to patents only if the inventor was "employed to invent" does not mean that he must originally have been hired to invent; it is enough that the duties to which he was assigned at the time contemplated the making of such an invention. ${ }^{19}$

Where the employee is entitled to ownership of his invention, the Government may obtain a common law "shop-right" therein whenever there is some contribution by the employer to the conception, development, or perfection of the invention or to its "reduction to practice," a contribution which may take the form of the use of the employer's materials, appliances, facilities, or equipment, or the aid of services of other employees, or may consist merely of the fact that the invention was made or perfected during the inventor's compensated working hours. ${ }^{20}$ The shop-right is,

${ }^{17}$ United States v. Dubilier Condenser Corp., sipra, note 9, at x93-196. Mr. Justice Stone, dissenting in that case, restated the rule adopted by the majority of the court as follows: "Wherever the employee's duties involve the exercise of inventive powers, the employer is entitled to an assignment of the patent on any invention made in the scope of the general employment." Id. at 2II-2r2.

The Fourth Circuit Court of Appeals defined the rule in somewhat different terms: If an employee "be set to experimenting with the view of making an invention," the discoveries made by him in the course of the experiments belong to the employer. Houghton v. United States, supra, note 9, at 390.

${ }^{18}$ Dissenting opinion of Justice Stone in United States v. Dubilier Condenser Corp., supra, note 9, at 214-219. The dissenting opinion, in which Justice Cardozo concurred and with which Chief Justice Hughes generally agreed, held that the Government should obtain title to inventions made by employees who, although "not engaged to invent, in the sense in which a carpenter is employed to build a chest, ... were employed to conduct scientific investigations in a laboratory devoted principally to applied rather than pure science with full knowledge and expectation of all concerned that their investigations might normally lead, as they did, to invention." Id. at 2II-212. In these circumstances, Justice Stone thought that the Government should have been awarded the patents under either the majority rule or under his definition of the applicable principles. Id. at $2 \mathrm{II}-2 \mathrm{I} 2,2 \mathrm{I} 7-2 \mathrm{I} 8$.

${ }^{10}$ Houghton v. United States, supra, note 9, at 390; Goodyear Tire \& Rubber Co. v. Miller, 22 F. 2d 353 (C. C. A. 9th 1927); cf. Magnetic Mfg. Co. v. Dings Magnetic Separator Co., 16 F. $2 d 739$ (C. C. A. 7th 1926); Johnson Furnace \& Eng. Co. v. Western Furnace Co., r78 Fed. 819, 823 (C. C. A. 8 th 19ro). The only unreversed decision to the contrary is Texas Co. v. Gulf Refining Co., I3 F. $2 d$ 873 (S. D. Tex. 1926), restricting the rule to original employment to invent.

In his dissenting opinion in the Dubilier case, Justice Stone pointed out that the majority had rejected "the distinction between specific employment or assignment and general employment to invent" (289 U. S. at 213). This distinction was threafter adopted by a state court in State Boiard of Education v. Bourne, 7 So. 2d 838 (Fla. 1942); but of. State v. Neal, I2 So. 2d 590 (Fla. 1943).

${ }^{30}$ United States v. Dubilier Condenser Corp., stipra, note 9, at 188-192; Gill v. United States, supra, note 15, at 433; United States v. Houghton, supra, note 9, at 388 ; Kelton v, United States, $32 \mathrm{Ct}$. Cl. 314 (1897); Shearer v. United States, supra, note 15; Knapp v. United States, $46 \mathrm{Ct}$. Cl. 6or, 631 (I9II).

In the earlier cases, the shop-right was thought to be based upon principles of equitable estoppel, so that in addition to the employer's contribution, express or implied consent by the employee to the employer's use of the invention was deemed essential. McClurg v. Kingsland, I How. 202 (1823); Hapgood v. Hewitt, stupra, note I6; Solomons v. United States, supra, note 9, at 346; Lane \& Bodley Co. v. Locke, I5o U. S. I93 (1893); Gill v. United States, supra, note 15, at 430 . The more recent cases ignore the factor of acquiescence. See the Dubilier and Houghton cases, supra. 
in effect, a royalty-free, nonexclusive, irrevocable, nontransferable license to make, use and sell the invention and its products. ${ }^{21}$

Even where the Government has no rights under common law principles in an invention made by an employee, it may have what amounts to a free license because of its sovereign immunity from suit. Prior to Igro a patent owner seeking compensation from the Government for the unlicensed use of his invention had to establish a contract by the United States to pay for such use. ${ }^{22}$ If the circumstances did not permit the inference of an agreement (for example, if the Government mistakenly asserted a supposed shop-right) ${ }^{23}$ the sole avenue of redress against the United States was by special act of Congress. ${ }^{24}$ By the Act of June 25, 1910, ${ }^{25}$ as amended on July $\mathrm{I}$, $1918,{ }^{26}$ patent owners were given the right to sue the United States in the Court of Claims for "reasonable and entire compensation" for the use of their inventions "without license" or "lawful right" by Government employees or contractors. ${ }^{27}$ This is the exclusive remedy, and no infringement suits may be brought against the Federal employee or contractor who makes or uses the patented invention. 28

However, the Act of Igro is by its own terms inapplicable to inventions made or owned by a Government employee. ${ }^{29}$ Thus the Act leaves the Government's shop-right in effect wherever it would arise under common law principles, ${ }^{30}$ and at

${ }^{21}$ Flannery Bolt Co. v. Flannery, 86 F. $2 d 43$ (C. C. A. 3d 1936); cf. Curtiss Aeroplane \& Motor Corp. v. United Aircraft Eng. Corp., 266 Fed. 7I, 77 (C. C. A. 2d 1920); Imperial Supply Co. v. Grand Trunk Ry., II East L. R. 340 (Can. I912); see Note, I6 A. L. R. I210 (Ig22). It may also authorize a contractor to make the patented article for the holder of the shop-right. Schmidt v. Central Foundry Co., 218 Fed. 466 (D. N. J. 1914), aff'd on other grounds, 229 Fed. 157 (C. C. A. 3d 1916).

${ }^{22}$ United States v. Burns, supra, note I5; United States v. Palmer, 128 U. S. 262, 272 (1888); Hollister v. Benedict Mfg. Co., II3 U. S. 59, 67 (1885); James v. Campbell, stupra, note 9, at 359; Eager v. United States, 35 Ct. Cl. 556 (1900); see Crozier v. Krupp, 224 U. S. 290, 304 (1912); cf. Kelton v. United States, supra, note 20, at 349.

${ }^{28}$ Knapp v. United States, supra, note 20, at 640 ; Davis v. United States, 23 Ct. Cl. 329 (1888); see Cramp \& Sons v. Curtis Marine Turbine Co., 246 U. S. 28,40 (rgr 8 ).

${ }^{24}$ Schillinger v. United States, I55 U. S. 163 (1894); United States v. Berdan Co., 156 U. S. 552 (1895); Belknap v. Schild, I6r U. S. 10, 17 (1896).

${ }_{25} 36$ STAT. 851 .

${ }^{26} 40$ STAT. 705. As so amended, the Act of rgro appears at 35 U. S. C. 568 (1940).

${ }^{27}$ After the Court of Appeals for the District of Columbia issued an injunction against infringement of a patent by an Army officer (Krupp v. Crozier, 32 App. D. C. I (1908)), the Act of Igro was passed and the injunction dissolved. Crozier v. Krupp, supra, note 22, at 305 . This Act was held not to protect a Government contractor against an infringement suit (Cramp \& Sons v. Curtis Marine Turbine Co., supra, note 23), and the statute was broadened to remedy this defect. Sce Richmond Screw Anchor Co. v. United States, 275 U. S. 331 (1928).

${ }^{28}$ Crozier v. Krupp, supra, note 22; Richmond Screw Anchor Co. v. United States, supra, note 27.

${ }^{20}$ A proviso in the Act states: "The benefits of the provisions of this section shall not inure to any patentee, who, when he makes such claim, is in the employment or service of the Government of the United States, or the assignee of any such patentee," nor shall this Act "apply to any device discovered or invented by such employee during the time of his employment or service." See 35 U. S. C. $\$ 68$ (1940). This provision was the result of a fear that the employee by virtue of his position might be able to induce the Government to use his invention rather than some competing device, and a belief that Government service may have "educated" the inventor to make his invention. Sec 45 Cong. Rec. $8758,8767,8769,8772-74,8782-85$ (I9ro).

${ }^{30}$ United States v. Dubilier Condenser Corp., supra, note 9, at 205-219; H. R. Doc. No. 1288, 6rst Cong., 2d Sess. 3-4 (I910), 45 Cong. Rec. 8757 (I910). 
the same time it preserves the Government's immunity from suits for the use of patented inventions made by a Federal employee even if the Government has no shop-right. $^{31}$ Indeed the immunity applies to inventions made prior to Federal employment, if the inventor is a Government employee when the claim of infringement is made..$^{32}$ The practical effect is to give the Government "limited licenses ... in the nature of shop-rights" under the inventions of all Government employees, regardless of the circumstances in which they were made, ${ }^{33}$ and the sole remedy for the use of such inventions is a special act of Congress. ${ }^{34}$

The Act of I9ro, giving a judicial remedy to patent owners for the Government's unlicensed use of their inventions, thereby immunized Federal employees and contractors against personal liability for such use. ${ }^{35}$ While the Act denied the remedy where the inventions were owned or made by a Federal employee, the employee or the contractor who used the invention in behalf of the Government would seem to be equally immune from personal liability. For in order to give effect to the Government's immunity from suits upon Federal employees' inventions-an immunity which Congress expressly preserved after considerable debate-it must extend to the Government's agents and contractors. One of the dominant purposes of the Act was to preclude interference with Federal functions through patent infringement suits against Government employees or contractors. ${ }^{36}$ This purpose, as well as the Government's immunity under its employees' patents, would be nullified if the Government's agent or contractor were subject to personal liability or to in. junction suits on account of the use of a Federal employee's inventions. ${ }^{37}$ Hence,

${ }^{31}$ Moore v. United States, 249 U. S. 487 (Igrg); National Electric Signaling Co. v. United States, 60 Ct. Cl. $338,340-343$ (1925); see 45 Cong. REc. $8758,8783-8785$ (I910).

${ }^{32}$ See note 29 , supra. This aspect of the proviso was apparently intended to guard against the possible use of official position to induce the Government's adoption of inventions for the advantage of the employee. See 45 Cong. Rec. 8785 (rgro).

${ }^{83}$ United States v. Dubilier Condenser Corp., 59 F. $2 \mathrm{~d} 38 \mathrm{r}, 382$ (C. C. A. $3 \mathrm{~d}$ r932), affirmed without reference to this statement 289 U. S. 178 (1933). This may prevent the making of an enforceable agreement by the Government to pay for the use of such inventions. See I4 CoMP. GEN. 396 (I934); Vulcanite Cement Co. v. United States, 74 Ct. Cl. 692, 705 (I93I); $c f$. National Electric Signaling Co. v. United States, supra, note $3 x$.

${ }^{34}$ See 45 Cong. REc. 8785 (1910). This remedy was successfully invoked in several instances, sometimes resulting in special appropriations of compensation for the Government's use of the invention. 45 STAT. $1349,138 \mathrm{r}$, enacted after findings by the Court of Claims pursuant to a Congressional reference, see Sen. Doc. No. 134, 69th Cong., rst Sess. (I926); 49 Strit. 2077, see 2 Rep. ATr'y Gen. 280-281. On other occasions, the special acts granted jurisdiction to the courts or otherwise waived the employee's disability under the rgro Act. Gates v. United States, $87 \mathrm{Ct}$ Cl. 358 (1938); Shearer v. United States, supra, note 15; same case, Ior Ct. Cl. I96 (1944); National Electric Signaling Co. v. United States, supra, note 31; same case, $76 \mathrm{Ct}$. Cl. 545, 57I (1933); Van Meter v. United States, 47 F. 2d I92, 195 (C. C. A. 2d I931). Special jurisdictional acts were sometimes enacted prior to the I9ro statute. See Dahlgren v. United States, I6 Ct. Cl. 30 (I880); Talbert v. United States, 25 Ct. Cl. I4I (I890).

${ }^{3}$ See cases cited note 28 , supra.

${ }^{30}$ See 45 Cong. Rec. 8776 (1910); Crozier v. Krupp, supra, note 22; Richmond Screw Anchor Co. v. United States, supra, note 27.

${ }^{37}$ See 45 Cong. Rec. 8772 (19ro); cf. Yearsley v. Ross Construction Co., 309 U. S. 18, $20-22$ (1940). To hold that the Federal employee may sue the Government officer or contractor who uses his patented invention would give the Federal employee greater rights (injunction, accounting and treble damages under Rev. STat. $\$ \$ 49$ I9, 4921 ( 1875 ), 35 U. S. C. $\$ \$ 67,70$ (1940) than the private patent owner, who is entitled only to "reasonable and entire compensation" under the Act of rgro. 
apart from the usual difficulties attending injunction and damage suits against Federal agents, ${ }^{38}$ the Act would seem to bar them on account of the use of an invention of a Government employee.

Apart from the Act of rgro, the Government may acquire a free license under an employee's invention if he elects to patent it without fee under the Act of 1883 as amended, ${ }^{39}$ but this statute does not alter such rights as the Government may have to an even greater interest in the invention. ${ }^{40}$

Like any private employer, the Government may by contract or regulation increase its rights in inventions made by its employees. The courts will enforce agreements between private employers and their employees, requiring an outright assignment of all rights to inventions made by the latter in the course of their employment, ${ }^{41}$ and similar contracts may validly be made by a Government agency. ${ }^{42}$ Such agreements may be entered into at the outset of employment or after employ-

${ }^{38}$ Prior to the Act of 19ro, the Supreme Court declined to enjoin the infringing $u s e$ of a patented article by a Government officer, holding that the suit was in effect one against the United States. Belknap v. Schild, I6I U. S. I0, 24-25 (1896), apparently overruling the contrary dictum in Cammeyer v. Newton, 94 U. S. $225,234-235(1876)$. In James v. Campbell, ro 4 U. S. 356, 359 (1881), the court expressed great doubt whether a patent infringement suit could be maintained against a public officer "who acts only for and in behalf of the Government." See also Hollister v. Benedict Mfg. Co., stupra, notc 22; but cf. Cramp \& Sons v. Curtis Marine Turbine Co., supra, note 23, at $40-41$.

The lower courts have generally denied injunctions and other relief, on grounds of public policy, against the manufacture of infringing articles. Dashiell v. Grosvenor, 66 Fed. 334 (C. C. A. 4 th $\times 895$ ), aff'd on other grounds, I62 U. S. 425 (1896); Firth Sterling Steel Co. v. Bethlehem Steel Co., 216 Fed. 755, 762 (E. D. Penn. 1914); Marconi Wireless 'Telegraph Co. v. Simon, 227 Fed. 906 (S. D. N. Y. 1915), aff'd, 23 I Fed. 1021 (C. C. A. 2d 19r6), reversed on other grounds 246 U. S. 46 (rgr8); Foundation Co. v. Underpinning \& Foundation Co., 256 Fed. 374, 376 (S. D. N. Y. 1919). But compare Krupp v. Crozier, 32 App. D. C. I (I908), reversed after enactment of the 1910 Act, Crozicr v. Krupp, 224 U. S. 290 (1912); Moffet v. Fiske, 5r F. $2 d 868$ (App. D. C. 1931), reversing, on the ground of a Government shop-right, a judgment for damages against a Navy officer on account of infringement of another officer's patent.

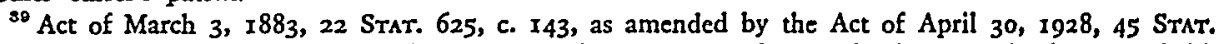
467 (1928), 35 U. S. C. $\$ 45$ (1940). Prior to the 1928 amendment, the lower Federal Courts held that a patent issued to an employee without fee under the 1883 Act was open to frec public use as well as Governmental use. Squier v. American Tel. \& Tel. Co., 21 F. 2d 747 (S. D. N. Y. 1924), affd on other grounds 7 F. $2 d 83$ I (C. C. A. 2d 1925); Selden Co. v. National Aniline \& Chemical Co., 48 F. 2d 270 (W. D. N. Y. 1930); Hazeltine Corp. v. A. H. Grebe \& Co., 21 F. 2d 643 (E. D. N. Y. 1927); Hazeltine Corp. v. Electric Service Eng. Corp., I8 F. 2d 662 (S. D. N. Y. 1926). The I928 amendment made it clear that the patents issued thereunder would be subject only to a free Government license, leaving the commercial rights in the employee. See United States v. Dubilier Condenser Corp., supra, note 9 , at $201-203,220-221$.

${ }^{10}$ See United States v. Houghton, supra, note 9, 20 F. 2d at 437; 39 Ops. ATr'y GEN. 402, 406 407 (1936); 37 id. 180,184 (1933).

${ }^{11}$ Guth v. Minnesota Mining \& Manufacturing Co., 72 F. 2d 385, 389 (C. C. A. 7th 1934), cert. denied, 294 U. S. 71 I (1935); Goodyear Tire \& Rubber Co. v. Miller, supra, note 19, at 355; Conway v. White, 9 F. 2d 863 (C. C. A. 2d 1925); see Hapgood v. Hewitt and Dalzell v. Ducber Mfg. Co., both supra, note I6; cf. Littlefield v. Perry, 21 Wall. 205, 226 (1874). The agreements may not be unreasonably broad, as by covering inventions completely unrelated to the employer's business and made after leaving employment. Guth v. Minnesota Mining \& Mfg. Co., supra. The available remedies include specific performance. Wage v. Safe Cabinet Co., 249 Fed. 696 (C. C. A. 6th 1918); Guth v. Minnesota Mining \& Mfg. Co., supra.

${ }^{42}$ McAleer v. United States, I5o U. S. 424 (1893); United States v. Houghton, 20 F. 2 d 434, 438, 439 (D. Md. I927), aff'd, 23 F. 2 d 386 (C. C. A. $4^{\text {th }}$ I928), cert. denied, 277 U. S. 592 (I928).

Reference to such agreements on the part of Government agencies will be found in 77 Cono. Rzc. 2626 (1933); 2 Rep. ATr'y Gen. 434, 436-7 (War Department); 2 id. at 387 (TVA). 
ment has begun, and will be effective in respect of inventions post-dating the agreement. ${ }^{43}$ The agreements will usually supersede such disposition as the common law would otherwise make of the invention, with one possible exception. While the Government may unquestionably contract for greater rights in its employees' inventions than it would otherwise acquire, an agreement to accept lesser rights may constitute a waiver of a governmental interest or a disposition of public property requiring statutory authorization. ${ }^{44}$

The distribution of rights as between the Government and its employees in the latter's inventions is subject to considerable control by administrative regulation, which, as a condition of appointment or of continued employment, can require the employee to assign to the United States (or to dedicate to the public) all rights to inventions made within the scope of employment. ${ }^{45}$ Congress has in fact impliedly approved a 1942 regulation of the Interior Department calling for the assignment of inventions made by its research employees in the course of duty, or made with a substantial contribution by the Government in the form of facilities, time, information, or the like. ${ }^{48}$ And for almost half a century, several Government agencies have had administrative regulations prescribing the respective rights of the Govern-

¿a Goodyear Tire \& Rubber Co. v. Miller, supra, note I9, at 355; Mississippi Glass Co. v. Franzen, 143 Fed. 50 I (C. C. A. 3d 1906). An employee may agree to give the private employer lesser rights, such as a license. Cf. Hildreth v. Duff, 143 Fed. $\times 39$ (C. C. W. D. Pa. Ig06).

"See Houghton v. United States, supra, note 9, at 39x. It has been suggested that such an agreement may also violate REV. STAT. $\$ 1765$ (1875), 5 U. S. C. $\$ 70$ (1940), prohibiting payment of extra compensation to a Government employee whose salary is fixed by law or regulation. See 2 REP. ATr'y GeN. 187 (1947). And there may be a lack of consideration. Cf. Vulcanite Cement Co. v. United States, supra, note 33 .

${ }^{*}$ Selden Co. v. National Aniline \& Chem. Co., 48 F. 2d 270 (W. D. N. Y. 1930), gave "the effect of law" to a regulation of the Department of Agriculture requiring public dedication of patented inventions "connected with the work of the Department" and made by an employee "through the expenditure of Government time and Government money." In Ig06 a Congressional Committee commended this regulation to all Federal agencies for adoption. See H. R. Doc. No. 8I47, 59th Cong., 2d Sess. 12 (1907). In United States v. Dubilier Condenser Corp., supra, note 9, the question of the administrative power to prescribe the respective rights in inventions of an employee was reserved as unnecessary to the decision ( 289 U. S. at 208). The dictum in that opinion, that "administrative officers" have "no power to declare" any policy as to the reciprocal rights of Government and employee in the latter's inventions, plainly refers to a declaration of rights after an invention has been made, and not to an antecedent regulation generally applicable to the department. This seems plain from other portions of the opinion ( 289 U. S. at $187-189, x 92$ ) recognizing the validity of a contract which fixes the respective patent rights of employer and employee, and citing McAleer v. United States, I5o U. S. 424 (1893), which enforced such a contract.

10 At the hearings on the Synthetic Liquid Fuels Act of 1944, Congress was apprised by the Secretary of the Interior of his 1942 regulation requiring employees of the Department to assign to the Government all inventions made within the general scope of their "governmental duties." Hearings before a Subcommittee of the Senate Committee on Public Lands and Surveys on $S$. 1243, 78th Cong., Ist Sess. 5-6, 9 (I943). After discussion of this regulation, 90 Cong. Rec. I708 (1944), Congress provided in the Act that patents acquired by the Secretary of the Interior thereunder shall be open to free public use. 58 Stat. I9I (1944), 30 U. S. C. $\$ \$ 323,324$ (Supp. 1946); 89 Cong. Rec. 9316 (1943); 90 id. 3209. This provision, enacted with notice of the departmental regulation and predicated upon the assumption that the Secretary would require an assignment of all inventions made by departmental employees under the Act, constitutes a form of Congressional ratification of the regulation itself. $C f$. Biddle v. Commissioner of Internal Revenue, 302 U. S. 573 (I938); Inland Waterways v. Young, 309 U. S. 517,525 (1940). 
ment and the employees in the latter's inventions. ${ }^{47}$ These regulations, and their consistent administrative application for so many years, add strength to the view that they fall within the departmental rule-making powers. ${ }^{48}$ Since the Tennessee Valley Authority (which is entitled by statute to ownership of all inventions made by its employees) ${ }^{49}$ is apparently the only Federal agency engaged in scientific research whose patent policy is now governed by Congress, all other agencies of the Government are free to adopt such patent policy as they deem proper..$^{50}$

Where the Government becomes entitled to ownership of the invention, it may enforce its rights by compelling an assignment of the patent or the application by the employee. ${ }^{51}$ This remedy must in fact be pursued if the benefits of the invention are to be extended to the public, since the Government's equitable ownership cannot be invoked by private persons as a defense to an infringement suit. ${ }^{62}$

\section{B. Current Patent Practice}

The patent practices of the several Government agencies in regard to inventions made by technical and professional employees engaged in scientific research and experimentation-the source of the great bulk of inventions produced by Federal employees-may be grouped generally into two categories.

r. Some agencies (notably Interior, Agriculture, the Bureau of Standards, and the Office of Scientific Research and Development during World War II) require an assignment of title to inventions made in the course of employment, if they bear a close relationship to the employee's functions, or if they involve a substantial Governmental contribution in the form of materials, facilities, equipment, services of

${ }^{17}$ See 2 REp. Atr'y Gen. 7-8 (1947) (Agriculture); 2 id. at 83, 98, I17-1 8 (Burcau of Standards and Weather Bureau); 2 id. at $183-185$ (Interior); 2 id. at 327-328 (OSRD); 2 id. at $498-499$ (WPB); 2 id. 426-427 (War); 2 id. $260-26 \mathrm{I}$ (Navy); 2 id. at 148 (Public Health Service).

18 United States v. Jackson, 280 U. S. 183 , I93 (I930); United States v. Johnston, 124 U. S. 236, 253 (1888). Besides the generally implied powers of each Federal agency to run its own affairs (United States v. McDaniel, 7 Pet. I, I4 (1833)), the head of cach department has long had the power "to prescribe regulations, not inconsistent with law, for the government of his department, the conduct of its officers and clerks...." REv. STAT. \$I6I (I875), 5 U. S. C. \$22 (1940). This authority was designed to promote efficiency and integrity in the discharge of official duties. Ex parte Curtis, 1o6 U.S. $37 \mathrm{I}$ (1882); cf. United States v. George, 228 U. S. I4 (1913). Unless plainly and palpably "inconsistent with law," administrative regulations issued under this statute will be respected by the courts and given the full force and effect of law. Caha v. United States, I52 U. S. 2II, 221 (1894); Ex parte Recd, roo U. S. I3 (I879); Boske v. Comingore, I77 U. S. 459 (I900).

50 The Tennessee Valley Act of I933, 48 STAT. 6I (I933), I6 U. S. C. \$83Id(i) (r940) provides that inventions made "by virtue of or incidental to" service by a TVA employee, "together with any patents which may be granted thereon, shall be the sole and exclusive property" of TVA, which may license them and pay the inventor such portion of the income therefrom "as it may deem proper." For the background of this provision, see 77 Cong. REc. 2626-29 (1933).

50 The regulations authorized by Rev. STat. $\$ 16 \mathrm{x}$ may take the form of either a formal, written regulation, or of general administrative practice. United States v. Birdsall, 233 U. S. 223 (1914); United States v. McDaniel, 7 Pet. I, I4 (x833); Haas v. Henkel, 216 U. S. 462 (1910); sec Benson v. Henkel, Ig8 U. S. I (I905).

${ }^{E 1}$ Houghton $\mathrm{v}$. United States, supra, note 9.

52 Yablick v. Protecto Safety Corp., 2x F. 2d 885 (C. C. A. 3d r927); Hazeltine Corp. v. Electric Service Eng. Corp., supra, note 39; Dubilier Condenser Corp. v. Radio Corp. of America, 34 F. $2 d 450$ (D. Del. 1929). 
other employees, or information not generally available. ${ }^{53}$ The practice of these agencies is in accord with that of virtually all laboratories operated by private industry, ${ }^{\sigma 4}$ by private research organizations, ${ }^{55}$ and by the principal foreign governments, ${ }^{56}$ which in general require inventions made by research workers to be assigned to the employer. ${ }^{57}$

2. The other Government agencies having a defined patent policy purport to apply the common-law principles governing the employee-employer relationship, but differ in the application of those principles. Only one-the Public Health Service-has to any appreciable extent called for an assignment of title; ${ }^{58}$ the others, although ostensibly enforcing the same policy, leave the patent to the employee in almost all cases and reserve only a free license to the Government. ${ }^{59}$

Wherever an agency (in either category) does not claim title to the employee's invention, it usually calls for a nonexclusive, royalty-free license to the Government. ${ }^{60}$ A few agencies apparently require a license only in circumstances where a commonlaw shop-right would arise in any event; ${ }^{61}$ others seem to demand a license regard-

5.3 The Department of the Interior, by a 1942 regulation, calls for the assignment of inventions made by employees within the general scope of their duties, or with a substantial use of Government facilities, a fact to be administratively determined; in other cases the employee retains title subject to a Government license. 2 REP. ATT'Y GeN. I83-I85. The War Production Board issued a similar regulation in January, 1944. $2 \mathrm{id}$. at 498-499. The Department of Agriculture for many years required assignment or public dedication of inventions relating to the Department's work or involving use of its facilities, in other cases taking a free license. Since the Dubilier decision in 1933, supra, note 9, the Department takes title only to inventions made within the employee's "specifically assigned duties," as administratively determined, but its actual application of this criterion has resulted in the assignment of the great majority of employees' patents. 2 id. at 13-14. 'The Weather Bureau follows Agriculture's policy. $2 \mathrm{id}$. at II7-120. The following have required an assignment of inventions made in the course of the employec's official duties: Bureau of Standards, 2 id. at 99; Food and Drug Administration, 2 id. at 152-153; Office of Scientific Research and Development in respect of its full time technical staff, 2 id. at 327-328; Signal Corps of War Department during World War II, 2 id. at 434-435; National Academy of Sciences and National Research Council, 2 id. at 223; American Printing House for the Blind, 2 id. at 154-155; and Aeronautics Branch of Department of Commerce until its transfer to the Civil Aeronautics Authority, 2 id. 123-127.

Es 3 Rep. ATt'y GeN. 62-65.

t5 3 id. at $53-54,73$.

${ }^{50} 3$ id. at 84 (Canada); 3 id. at ro7-r98 (Great Britain); 3 id. at Iro (France); 3 id. at III-II3 (pre-Nazi Germany); 3 id. at II5-116 (prewar Japan).

${ }^{87}$ This is also the practice in about half of the educational institutions in the United States, $3 i d$. at 55 .

${ }^{88} 2$ Rep. Att'y Gen. 148-I49.

${ }^{60}$ War Department (except Signal Corps, see note 53 supra) 2 ReP. Atr'Y GeN. 427-428; Navy Department, 2 id. at 259-266; National Advisory Committee for Aeronautics, 2 id. at 229-230; Public Roads Administration and Public Buildings Administration, 2 id. at $x 60-162$; Civil Aeronautics Authority, 2 id. at I26-127; and Bureau of Census, 2 id. at III-112.

${ }^{\circ 0}$ Such a license is usually Government-wide. 2 REP. ATT'Y GEN. 12-13, IIx, II7-I18, 126, I84$185,272-273,441-443$. Prior to World War $\mathrm{I}$, some agencies limited their licenses to the particular agency or bureau, a practice criticized by a Congressional Committee in I907. 2 id. at 6, Ix6-I 7 . The written licenses obtained by the War and Navy Departments permit use of the invention "by or for" the Government, a statutory phrase which covers use by Government contractors as well as employees. See note 27, supra. Even without such a provision, a license to the Government would probably protect contractors, under the analogy to a common law shop-right. See note 2I, supra.

${ }^{\circ}$ Interior Department, 2 REP. ATr'Y GEN. 176; Public Health Service, id. at I48; Public Roads Administration, $i d$. at 160 . The War Department apparently restricts its licenses to inventions made in the course of official work, id. at 426 . 
less of the circumstances. ${ }^{62}$ The Government's immunity from suit on an employee's patent tends to give such a license a limited significance, principally as an argument against relief by special Act of Congress. ${ }^{63}$

The diversity of patent policy throughout the Government may in part be attributable to the lack of clarity of the common-law rules governing the disposition of patent rights. Prior to 1933 the rules were frequently restated in varying terms, ${ }^{04}$ and even when the Supreme Court purported to settle the matter in the Dubilier case, it divided six to three as to the application of the majority's rule to the facts at hand. ${ }^{65}$ But the principal explanation of the fact that an identical formula, adopted by three agencies (Agriculture, War, and Navy), ${ }^{60}$ has resulted in Government ownership of most inventions made in Agriculture, ${ }^{67}$ and employee ownership of virtually all inventions in the War and Navy Departments, ${ }^{08}$ lies in a difference of opinion as to whether the Government or private interests should control the commercial rights to inventions financed with Federal funds. For instance, although the research operations of the War and Navy Departments during World War II exceeded those of any other agencies, and unquestionably involved the assignment of technical staffs to the solution of specified research problems (the factors which would normally entitle the employer to the resulting inventions), neither department has asserted title to an invention except in isolated instances. ${ }^{60}$ This is not readily explainable except in terms of the general policy of those agencies. ${ }^{70}$

${ }^{62}$ Agriculture Department, 2 ReP. ATr'Y GeN. 8; Navy Department, id. at 260.

${ }^{03}$ See notes 24 and 34 , supra. The use of a written license proved useful prior to the 1910 Act since establishment of the shop-right frequently required litigation, and in the meantime did not prevent the indirect charge of royalties to the Government via the contractor or supplier. See 2 REp. ATT'Y GEN. II0, $257,258$.

os Thus, it has been held that the Government (or other employer) would be entitled to ownership if the employee is "specially employed to make experiments with a view to suggest improvements," United States v. Burns, supra, note 16 ; if he "is employed to devise or perfect" the instrument or means which he invented, Solomons v. United States, supra, note 9; if there is an express agreement to that effect, Hapgood v. Hewitt, and Dalzell v. Dueber Mfg. Co., both supra, note 16; if he is "cmployed to invent or devise" the improvements, Gill v. United States, supra, note 15, at 432.

${ }^{65}$ United States v. Dubilier Condenser Corp., supra, note 9. The majority (Justices Roberts, Van Devanter, McReynolds, Butler, Brandeis, and Sutherland) held that the Government was not entitled to the patents on inventions which employees had been permitted but not expressly instructed to makc, 289 U. S. 178, 193-196; the minority (Chief Justice Hughes and Justices Stone and Cardozo) thought Government ownership was justified by the fact that the employees had developed the inventions in the course of their official functions at the Government's laboratory, during regular hours and with their supervisors' approval. Id. at $2 \mathrm{II}$ et seq.

${ }^{B 0}$ Purporting to restate the rule in the Dubilier case, supra, note 9 , the regulations of these three agencies provide that the Government shall be entitled to the ownership of inventions made within the employee's "specifically assigned duties." 2 REP. ATT'Y GEN. 12, 265, 427.

67 2 REP. ATT'Y GEN. 25.

${ }^{48} 2$ id. at $266-269,428-43$. The contrary practice of the Signal Corps during the war is based upon a bureau regulation differing from the departmental regulations. $2 i d$. at 434 .

${ }^{60} 2$ id. at $259-266,427-428$.

${ }^{70}$ For many years the regulations of both the War and Navy Departments provided for no morc than a Government license regardless of the circumstances in which the invention was made. 2 id. at 4I4-427. The Naval Ordnance Laboratory uses an "employment agreement" which apparently limits the Government to a free license $(2$ id. at 268 ) and the Navy recently expressed the view that scientific research workers in the Government should retain title to their inventions in all circumstances, subject only to a Government license, 3 id. at 302 . 


\section{Considerations Bearing Upon a Sound Policy}

The basic requirements of a sound patent policy are noncontroversial: it must serve the public interest by encouraging the fullest and widest use of the inventions of Federal employees, and at the same time it must encourage or at least not discourage future research and invention by such employees. The controversy arises in determining whether those objectives will best be achieved by private control or by public control of the commercial patent rights in such inventions. ${ }^{11}$

Two jurists have expressed cogent arguments for Government ownership of inventions resulting from the official activities of Federal research workers. In I933 the late Chief Justice Stone (then Associate Justice), in a dissenting opinion in the Dubilier case with which Justice Cardozo concurred, expressed the view that the United States was entitled to inventions made by Government employees in the course of scientific research carried on in a Government laboratory with official approval:

The inventors were not only employed to engage in work which unmistakably required them to exercise their inventive genius as occasion arose; they were a part of a public enterprise. It was devoted to the improvement of the art of radio communication for the benefit of the people of the United States, carried on in a government laboratory, maintained by public funds. Considerations which might favor the employee where the interest of the employer is only in private gain are therefore of slight significance; the policy dominating the research in the Bureau, as the inventors knew, was that of the government to further the interests of the public by advancing the radio art. For the work to be successful, the government must be free to use the results for the benefit of the public in the most effective way. A patent monopoly in individual employees, carrying with it the power to suppress the invention, or at least to exclude others from using it, would destroy this freedom; a shop-right in the government would not confer it. For these employees, in the circumstances, to attempt to withhold from the public and from the government the full benefit of the inventions which it has paid them to produce, appears to me so unconscionable and inequitable as to demand the interposition of a court exercising chancery powers. $\ldots .^{2}$

Declaring that the majority decision permitting the employees to retain the inventions "is repugnant to common notions of justice and policy," Justice Stone continued:

The case would be more dramatic if the inventions produced at public expense were important to the preservation of human life, or the public health, or the agricultural resources of the country. The principle is the same here, though the inventions are of importance only in the furtherance of human happiness. In enlisting their scientific talent and curiosity in the performance of the public service in which the Bureau was engaged, Dunmore and Lowell necessarily renounced the prospect of deriving from their work commercial rewards incompatible with it. Hence, there is nothing oppressive or unconscionable in requiring them or their licensee to surrender their patents at the instance of the United States, as there probably would be if the inventions had not been made

71 The numerous studies and reports and the divergent opinions in this field since rg00 are summarized in 3 REP. ATT'Y GEN. 167-314.

${ }^{72}$ United States v. Dubilier Condenser Corp., supra, note 9, at 217-218. 
within the scope of their employment or if the employment did not contemplate invention at all. ${ }^{73}$

Chief Justice Hughes agreed with Justice Stone's "analysis of the facts" and his "conclusions as to their legal effect," adding:

As the people of the United States should have the unrestricted benefit of the inventions in such a case, I think that the appropriate remedy would be to cancel the patents. ${ }^{74}$

The majority decision in that case held the employees entitled to retain the inventions under the common-law rule because their duties did not "contemplate invention," but it did not attempt to justify the rule on grounds of policy. ${ }^{75}$ In fact, the agency there involved (the Bureau of Standards) found the majority decision so unsatisfactory as a matter of policy that it immediately promulgated a regulation, which is still in effect, calling for the assignment of all patent rights to inventions made by employees in the course of employment. ${ }^{76}$

A few years earlier, a Federal Circuit Court of Appeals, upholding the Government's title to the invention of an employee of the Public Health Service, made essentially the same point made by Justice Stone. Speaking for a unanimous court, Circuit Judge Parker said:

... there would be less reason in allowing an employee of the Public Health Service to withhold a patent from the government than in allowing an employee to withhold a patent from a private charitable organization. The Public Health Service represents the people of the United States. Its interest is their interest. Its investigations and discoveries are made for their benefit. And although neither it nor they have any interest in monopolizing inventions which may be made in the course of its studies and experiments, both have an interest in seeing that these inventions are not monopolized by any one. In the case of the fumigant gas developed by the defendant while employed and paid by the government to develop it, they are interested, not only in the use which the Health Service itself may make of it, but also and primarily in having it supplied to the public as freely and cheaply as possible. It is unthinkable that, where a valuable instrument in the war against disease is developed by a public agency through the use of public funds, the public servants employed in its production should be allowed to monopolize it for private gain and levy a tribute upon the public which has paid for its production, upon merely granting a nonexclusive license for its use to the governmental department in which they are employed. . . .77

The same views have been voiced in the halls of Congress. During consideration by the Senate of a bill authorizing the Bureau of Mines to construct and operate demonstration plants for the production of synthetic liquid fuels, Senator Austin of Vermont, after learning of the Interior Department's regulation providing for Government ownership of inventions made by its research employees, proposed an amendment authorizing public dedication of patents acquired under the Act. ${ }^{78}$ Ex-

${ }^{73} 1 d$. at $218-219$.

${ }^{75} I d$. at r97-199.
${ }^{77}$ Houghton v. United States, 23 F. $2 d$ REP. ATT'Y GEN. 98 .
386,39 (C. C. A. 4 th I928), cert. denied, 277 U. S. 592

74. Id. at 224 . (x928).

${ }^{78} 89$ Cong. Rec. 9316, 9320 (Nov. 9, 1943); 90 id. 3187, 3207 (March 28, 1944). The bill became the Synthetic Liquid Fuels Act of April 5, I944, 58 STAT. I91 (1944), 30 U. S. C. \$5323, 324 (Supp. 1946). 
plaining his proposal, Senator Austin expressed the opinion (shared by Senator O'Mahoney of Wyoming) that:

... the door must be kept open to private enterprise for all discoveries in science made at the cost of the United States, or by the agencies of the United States, just as freely as physicians, under their Hippocratic oath, give their special knowledge and skill to all humanity. ${ }^{79}$

Similarly, during the Senate debates on the Tennessee Valley Act of 1933, a group of Senators ${ }^{80}$ successfully supported a provision for Government ownership of inventions made by TVA employees, on grounds equally applicable to all Government agencies. Their views were summarized by Senator King of Utah, who pointed out that scientists engaged in research work at private industrial laboratories had to turn over the patents on their discoveries to the employer:

... the government has maintained at great expense plants, laboratories, and stations in which are conducted scientific investigations. . . Scientific men have been and are engaged in this work. ... They were not employed to prosecute private or individual scientific investigations, but to give of their time and of their ability to make discoveries and improvements that would be not only of advantage to the Government, but with the consent of the Government, to the entire country. ...81

More recently, spokesmen for educational institutions and for organizations of scientific, professional, and technical workers also have urged a policy of public control of patentable discoveries resulting from Federally financed research. The views of these groups are exemplified in the statement of Dr. Horace M. Gray, Associate Dean of the Graduate School of the University of Illinois, presented in October, 1945, at the hearings held by a Subcommittee of the Senate Committee on Military Affairs (popularly known as the "Kilgore Subcommittee"), on a bill providing for a Federally supported program of scientific research: ${ }^{82}$

It is really quite unthinkable that the Federal Government should tax the citizens of this country to secure funds for scientific research, on the ground that such research promotes the general good, and then turn the results of such research over to some private corporations on an exclusive, monopoly basis. This amounts to public taxation for private privilege and violates one of the basic tenets of our democratic faith.

There is no escape from the simple and fundamental truth that new discoveries derived from research supported by public funds belong to the people and constitute a part of the public domain to which all citizens should have access on terms of equality. ${ }^{83}$

${ }^{70} 89$ Cong. Rec. 9316 (Nov. 9, 1943).

${ }^{80}$ Senators Norris of Nebraska, King of Utah, Robinson of Arkansas, Fess of Ohio, and Dill of Washington.

${ }^{82} 77$ Cong. Rec. 2626 (1933). Senator Smith of South Carolina agreed, saying: "We ought to provide some means by which the Government would hold its hand on those discoveries of genius which revolutionize our organized society and not turn them over to corporations." Id. at 2629 . In the course of these debates, Senator Dill suggested that Congress should provide by statute for Government ownership of the inventions of all Government employees, especially in "the light of the recent decision of the Supreme Court" in the Dubilier case. Id. at 2627 .

${ }^{82}$ Hearings before the Subcommittee on War Mobilization of Senate Committee on Military Affairs on S. 1297, 79th Cong., Ist Sess. 291-292, 295 (1945). The record of these hearings will be cited as Kilgore Hearings.

${ }^{83}$ To the same effect was the testimony at these hearings given by spokesmen for the International 
These principles received endorsement from President Truman, ${ }^{84}$ a number of high government officials with experience in the field of scientific research, ${ }^{85}$ and many prominent scientists and engineers. ${ }^{86}$

Spokesmen for American industry have also advocated Government ownership and public dedication of inventions made by Federal employees, ${ }^{87}$ a position which may in part be traceable to actual experience with the opposite policy. In at least two instances, Federal employees who were left with commercial patent rights granted exclusive rights to one of a number of competing companies, creating considerable resentment on the part of the companies which found themselves subject to their competitor's power to deny them, or to charge them for, the use of technology financed with public funds. ${ }^{88}$

Those who have expressed disagreement with a policy of Government ownership of inventions made by Federal employees-principally spokesmen for the War and Navy Departments-do not as a rule contend that the public interest will be better served by entrusting publicly financed technology to private monopoly. Their objections are grounded almost entirely upon the contention that the grant of the commercial patent rights to the employee is a necessary means by which to attract

Federation of Architects, Engineers, Chemists and Technicians, id. at $843-844$; the American Federation of Labor, id. at II9; the National Farmers Union, $i d$. at I29; the Congress of Industrial Organizations, id. at 86x; the Independent Citizens Committee of the Arts, Sciences and Professions, id. at 1002; and the Association of Oak Ridge Scientists, id. at 320 .

84 In a special message to Congress in September, 1945, the President recommended legislation which makes "fully, freely, and publicly available to commerce, industry, agriculture and academic institutions, the fruits of research financed by Federal funds" in order that we may "derive the full profit in the future from what we have learned." (Reprinted in NATIONal ScIence Foundarton, Report No. 8 on Science Legislation from the Subcomaitiee on War Mobjlization to the Senate Committee on Military Affairs, 79th Cong., 2d Sess. 39-40 (1946).

${ }^{85}$ Secretary of Commerce Henry A. Wallace, Kilgore Hearings, supra, note 82, at I42; Commissioner of Patents Casper W. Ooms, id. at 701; Director of the Budget Harold D. Smith, id. at ro2; Secretary of the Interior Harold L. Ickes, id. at 343-344; Dr. J. C. Hunsaker, Chairman of the National Advisory Committee for Aeronautics, id. at II3-II4, II6; Maury Maverick, Chairman of Smaller War Plants Corporation, id. at 372; Col. Bradley Dewey, President of the American Chemical Society and the wartime Rubber Director of the Federal Government, $i d$. at 822; Bernard M. Baruch, unoficial adviser of the President, id. at 911, 921-922; and P. V. Cardon, Agricultural Research Administrator of the Department of Agriculture, id, at 729 .

${ }^{80}$ Dr. Harlow Shapley, Director of Harvard University Observatory, IgI Harpers 3I4, 317 (Oct. 1945); Dr. Francis G. Blake, Dean of Yale University School of Medicine, Kilgore Hearings, supra, note 82, at 476; Dr. Thorndike Saville, Dean of Engineering, New York University, id. at roo6; F. Malcolm Farner, Fellow and past president of American Institute of Electrical Engineers, id. at 722; Dr. Harold C. Urey of the University of Chicago, id. at $66 \mathrm{I}$; and many other scientists and educators, id. at 543 , $580,604,61_{3}, 895,1030,1088,1148$, Ix86.

${ }^{87}$ Kilgore Hearings, supra, note 82, at $181,419,425$, 1188 ; Hearings before the Special Senate Committee on Atomic Energy on S. 1717, 79th Cong., 2d Sess. 301 (1946).

${ }^{88}$ After research employees of the Naval Research Laboratory sold the commercial patent rights in certain important inventions, several complaints were received in 1927 from private companies, protesting that they were required to pay royalties to a competing company in order to use inventions developed in a public laboratory at public expense. The head of the Radio Corporation of America suggested that all companies should be entitled to nonexclusive licenses under such patents. 2 Rep. ATr'y Gen. 271. A similar situation was encountered in the Burcau of Mines prior to the 1942 Intcrior Department regulation providing for Government ownership of its employees' inventions, 2 id. at 177I78; and, before the turn of the century, in the Department of Agriculture, $2 i d$. at $4-6$. 
and retain qualified research workers, and to stimulate their inventive faculties. ${ }^{89}$

In appraising the soundness of this view, one is struck by the fact that every organization of scientific, technical, and professional workers which recently appeared before the Kilgore Subcommittee advocated precisely the opposite policy-one which would deny them personally any rights in inventions financed with Federal funds. ${ }^{80}$ This position on the part of those who would presumably benefit from the retention of commercial patent rights seems to be quite representative of men of science everywhere. The late Chief Justice Stone judicially observed that "many scientists in the employ of the Government regard the acceptance of patent rights leading to commercial rewards in any case as an abasement of their work,"91 and the Commissioner of Patents, testifying before the Kilgore Subcommittee in 1945, struck the same note:

The argument has often been made that unless employees of a bureau . . . are permitted to retain some part of the rights to inventions produced by them while in the Government service, employees of necessary competency cannot be procured at the salaries the Government is ready to pay. I am not persuaded that this is true.

We have in the Patent Office hundreds of competent men, trained and working in scientific fields. They are forbidden by law to acquire interests in patents except by bequest or inheritance. Their devotion to their work is no less because of this restriction upon their right to acquire property, and you may be assured that they are confronted with the same rather low compensation scale that prevails in many Government bureaus. ${ }^{92}$

The Government's experience during the past five decades adds factual weight to these opinions. The Office of Scientific Research and Development, which spent almost half a billion dollars on research during the period r940-I946, has found entirely satisfactory its policy of requiring the assignment of all rights to inventions made by its technical personnel. ${ }^{93}$ Federal agencies which have tried both policies are unanimous in the belief that to deny commercial patent rights to their employees does not affect the ability to attract and retain competent research and technical

${ }^{80} 2$ REP. ATT'Y GEN. $273-275,453 ; 3$ id. at 24I-242, 270, 302. It is interesting to note that the current regulations of the War and Navy Departments (although not their actual practice thereunder) are basically inconsistent with the policy position taken by these Departments. Purporting to follow the common law rules, these regulations provide for Government ownership of all inventions made by employees within their specifically assigned duties. 2 id. at 265,427 . If patent rights are a necessary incentive to the Federal employee, it seems illogical to deny the incentive in the very situation where the Government is most desirous that an invention result-i.e., where the employee has been explicitly assigned or directed to make the invention.

${ }^{00}$ See notes $82-86$, supra.

${ }^{02}$ In his dissenting opinion (with which Justice Cardozo concurred) in United States v. Dubilier Condenser Corp., supra, note 9, at 218.

${ }^{92}$ Kilgore Hearings, supra, note 82 , at 701 .

${ }^{93} 2$ REP. ATT'Y GEN. 327-328. While the research sponsored by OSRD was carried out by contractors or by other Federal agencies, and not in laboratories of OSRD, the technical personncl of OSRD assisted contractors in solving the assigned problems, made suggestions and gave general directions concerning the technical aspects of the problems, and coordinated the efforts of the contractors with those of the Armed Services. 2 id. at 328. 
personnel, nor the productivity or quality of their work. ${ }^{04}$ The practice of the Signal Corps of the War Department during World War II, reserving the commercial patent rights to the Government, represents a conspicuous deviation by one bureau from departmental practice; nevertheless, under that policy the Corps' personnel produced a greater number of inventions than any other bureau of the War Department. ${ }^{95}$ The personnel of industrial and institutional research organizations have produced a wealth of inventions during the past decade, although operating for the most part under a policy requiring the assignment of patent rights to the employer. ${ }^{08}$ To this evidence of experience may be added the clear inference to be drawn from the very existence of diverse patent policies in the Government. 'Since the Government's salary scale is fairly uniform for like functions and responsibility, the fact that "title" agencies such as the Bureau of Standards, the Department of Interior, and the Department of Agriculture have apparently had no difficulty in adequately staffing their research sections, even though a more liberal patent policy was available at the War and Navy Departments, would indicate that the grant of commercial patent rights to the Federal employee is not necessary to attract and retain able personnel and to stimulate their inventive output. ${ }^{97}$

While the agencies which adopted a policy of Government ownership have generally continued it in effect to date, several agencies which as a rule leave the commercial patent rights to the employee have tended to disapprove of their own policy and to criticize its weaknesses and dangers. ${ }^{98}$ The consensus of informed persons lists a number of objections to a policy which leaves the commercial patent rights to the Federal employee:

I. Outside organizations, including Government contractors, may be reluctant to open their files and their technical information to the Federal Government if the Federal employees with whom they deal may appropriate and patent the inventive ideas thus suggested or disclosed. This point was made by Dr. Vannevar Bush, Director of OSRD and head of the Carnegie Institution of Washington, in an official explanation of OSRD's regulation requiring its technical personnel to assign inventions made in the line of duty:

24 This is true of the Department of Agriculture, 2 id. at $16,20-22,37$, the Department of Interior, 2 id. at $183-184,194-195$, the National Bureau of Standards, 2 id. at $82-83,102$, and the Signal Corps of the War Department during World War II, 2 id. at $432-436$.

g5 2 id. at $432-436$.

oc 3 Rep. ATT'Y GEN. 53-55, 62, 66-67; Hearings before Subcommiltee of Senate Commiltee on Military Affairs on $S_{-}$702, 78th Cong., Ist Sess. Pt. I, 16 (1943); id., Pt. 6, at 715; id., Pt. 7, at $963-964$.

${ }^{97}$ It may be noted that Lowell, one of the inventors involved in the Dubilier case, left the Bureau of Standards for outside employment as a result of the controversy. Some years later he returned to the Bureau and, under the new regulations of the Bureau, agreed to assign to the Government all future patented inventions resulting from his employment. 2 REP. ATr'Y GEN. 102. For a similar incident in the Department of Agriculture, see 2 id. at 6.

${ }^{88}$ National Advisory Committee for Aeronautics, 2 REP. ATT'Y GEN. 230 at seq; Federal Sccurity Agency, $3 \mathrm{id}$. at $30 \mathrm{r}$; and even the Navy Department during the Twenties, when all important research bureaus other than the Naval Research Laboratory recommended adoption of the assignment policy for research personnel. This recommendation was not adopted because of a ruling of the Judge Advocate General that the change was not permitted by law. $2 i d$. at 262-264. This view seems to be crroneous. See notes $4 \mathrm{I}-50$, supra. 
Much of the effectiveness and smooth functioning of OSRD is due to the competence, diplomacy and impartiality of these technical personnel who enjoy to a high degree the confidence of OSRD contractors and of the Armed Services. An important factor in creating this confidence is the realization that the technical personnel of this Office are not seeking to establish rights for themselves as individuals in the fields of research and development for which they are acting as the Government's representatives. ${ }^{99}$

To the same effect is the explanation advanced in 1944 by the Signal Corps in justification of its wartime policy of calling for title to its employees' inventions:

We needed the closest possible liaison between our own and the commercial laboratories; and we found the commercial outfits reluctant to disclose their newest ideas to men who might use those ideas as springboards toward improvements, on which improvements the contractor might later be asked to pay royalties. ${ }^{100}$

So also wrote the Director of the Bureau of Standards in I928:

I feel that if the time ever comes when it is recognized that Bureau employees may freely take patents along the line of their work in the Bureau and have a monopoly in the disposal of such patent rights that the reputation of the Bureau will suffer, that the confidence of industry in the work of the Bureau and the usefulness of the Bureau to industry will be seriously impaired; and that there is danger that the wholehearted cooperation with industry which the Bureau has always enjoyed in remarkable measure will suffer. Certainly these results will follow in greater or lesser measure if the impression gets abroad that our employees are competing with industry rather than bending their undivided energies to its assistance. ${ }^{101}$

2. Several Government officials have warned that the prospect of profiting personally from patent rights may lead to lack of harmony and cooperation within the research organization itself, and to secretiveness on the part of the employees who fear to be outdistanced in their individual race towards a patentable invention. ${ }^{102}$ It was this factor which led the University of Chicago to decree that neither the University nor its faculty members shall derive any profits from patents:

The advancement of scientific knowledge depends on the free interchange and use of the ideas and information between scientists and research workers within a university. The basic purpose of university research may be thwarted if the free exchange or use of such information is checked or prevented by the attempt of one or a group of faculty members to profit from patentable discoveries. By removing any such incentive, the

${ }^{\circ 0}$ OSRD Administrative Circular 10:06, Sept. 15, 1943, quoted in 2 REP. ATT'Y GEN. 328. In the same year, Dr. Bush told the National Patent Planning Commission that "the conditions of employment, the salaries, and . . . the security of a government post should be made adequate to secure appropriate personnel," and he characterized as "inherently dangerous" the adding of an "artificial incentive," such as the "possibility of profit from commercial rights in incidental inventions." Ibid.

${ }^{100} 2$ REP. ATT'Y GEN. 435. Another reason for the Signal Corps' policy was to allay rumors that private companies were purchasing worthless patents from employees as a form of concealed payments for favors received. Ibid.

1012 id. at ror.

102 The National Advisory Committee for Aeronautics (see Report No. 5, cited supra, note 4, Pt. I, 184) and almost all bureau chiefs and research officials within the Department of Agriculture. 2 REP. ATT'Y GeN. 20. 
patent rule of the University of Chicago insures that the cooperative search for truth is untrammeled. 103

3. According to several competent authorities in the field, the Federal employee's right to retain the commercial patent rights to his inventions may make him excessively "patent-conscious," leacing to neglect of his duties in favor of research more likely to result in personal profit, and also to concentration of his efforts upon "working around" the prior art in order to evolve a readily patentable idea, rather than the quickest solution of the assigned problem. ${ }^{104}$ In the words of the Bureau of Standards,

... research workers ... will not be able to give their best efforts to the government if thcy are distracted from the main end in view by searching for patentable ideas along the lines of their official endeavors to inure to their own benefit. Yet if patents are to be freely granted it will be very difficult for men to avoid such considerations, whether consciously or unconsciously. ... 105

That this.danger is not purely theoretical may be seen from the experience of the Naval Research Laboratory, which under its policy of leaving the commercial patent rights to its employees, admittedly encountered "a good many . . . troubles . . . such as technical employees giving too much attention to patents and outside work."100 In fact, the laboratory has found it necessary to issue a regulation forbidding the "prosecution of research on matters which might have a commercial application ... to the detriment of assigned problems" having no such promise. ${ }^{107}$

4. The employee's retention of patent rights may disable him from acting in the field in which he is most expert, lest he use his official position to encourage the Government's use of his own rather than a competing invention. This possibility has in fact led the War Department to disqualify some of its most valuable men from serving in a field in which they have obtained patents. ${ }^{108}$

5. Commercial patent rights are an inequitable and unfair form of incentive to Federal research workers because, as the Commissioner of Patents observed,

Those working on profound fundamental problems that seldom yield readily utilizable inventions would be prejudiced as compared to those working nearer the fringe of industrial applications, although the latter may frequently be engaged upon less important and less difficult problems. ${ }^{109}$

103 The Patent Policy of the Universtty of Chicago and Its Relation to Riesearcil (Bullctin issued by Business Problems Bureau of University of Chicago, March 15, 1944). See 3 Rep. ATr'Y Gen. 2r. The same point has been made by scientists appearing before the Kilgore Subcommittec. Sce Kilgore Hearings, supra, note 82, at 991; see also il. at 488,616, 1059-1060, 1068 .

106 This point was made in 1945 by the Commissioner of Patents before the Kilgore Subcommittee, Kilgore Hearings, supra, note 82, at 701, and also by Dr. J. C. Hunsaker, Chairman of the National Advisory Committee for Aeronautics, id. at 116.

${ }^{205} 2$ REP. ATT'Y GEN. IOI-I02. The same idca was expressed by the University of Chicago in its Bulletin, supra, note I03.

${ }^{100} 2$ REP. ATT'Y GEN. 270. $\quad{ }^{107} 2$ id. at 27 r.

${ }^{108} 2$ id. at 448 . The problem becomes even more acute when the employec contracts in advance to turn over all future inventions to a private concern, as his happened in the War and Navy Departments, 2 id. at $269-271,449,45^{\circ}$.

${ }^{100}$ Kilgore Hearings, supra, note 82 , at 701 . 
Moreover, it may be difficult to select one or several out of a large group of research workers as the recipient of the rights to an invention which all collaborated in producing. And even among inventors receiving patent rights the reward is unequal, since the financial returns would depend upon fortuitous commercial factors having little relationship to the difficulty of the discovery or its importance to the public. $^{110}$

6. Perhaps the most serious objection leveled against the policy of leaving patent rights to the employee is its effect upon the public. It has been argued that if the compensation of Federal research and technical employees must be supplemented to make their positions more attractive, the defect should be supplied by increasing the salaries or other emoluments of office, rather than by vesting the employee with the power to suppress, or to levy a private toll for the use of, an invention financed with public funds. This objection gains acuity from the well-recognized fact that the Government employee is generally in no position to exploit or manufacture the invention, and must therefore sell or exclusively license it for commercial exploitation by a private concern. ${ }^{111}$ That concern will of course use the invention according to its best interests, and if those interests will be better served by complete suppression in order to protect an investment in earlier technology, the invention will be suppressed. $^{112}$ Clearly, a nonexclusive Government license alone cannot guarantee the fullest public benefit from the invention, nor prevent a private toll for the use of publicly financed technology, nor assure against its complete suppression; it is only Government ownership or control of the invention that can place the public interest first, and either open to the public the technology which public funds have financed, or, if conditions upon its use are desirable, frame those conditions in the public interest.

Essentially for the reasons discussed above, the Attorney General, in his Report to the President in May, I947, recommended the adoption of a uniform policy for the Government under which the United States would receive all rights to inventions made by its employees during working hours, within the scope of their official functions, or with a substantial contribution from the Government. He further recommended that where there is some Governmental contribution to the invention or some relationship between the employee's official functions and the invention, but these are insufficient to warrant the assignment of all rights to the Government, the employee may retain the commercial rights subject to a royalty-free, nonexclusive license in the Government, and also subject to an obligation to make the invention available to the public on reasonable terms. ${ }^{113}$ This policy would seem to be thoroughly justified by the Government's experience during the past fifty years.

${ }^{210}$ Commissioner of Patents Ooms characterized the grant of commercial patent rights to Federal employees as making Government service "a lottery with big stakes." Ibid.

111 The experience in the agencies which permit the employee to retain the patent rights is that he almost always sells it to a company operating in the field. 2 REP. ATT'Y GEN. 24, 5I, 55, I72-173.

112 See Continental Paper Bag Co. v. Eastern Paper Bag Co., 210 U. S. 405 (I908); Special Equipment Co. v. Coe, 324 U. S. 370,378 (I945).

${ }^{213}$ I REP. ATT'Y GEN. 19, 56-62. 


\section{III \\ The InVEntions of Governmént Contructors}

A major portion of the research and devolopment activities financed by the Federal Government is carried on by outside organizations, under contracts or other arrangements with the United States. For example, of $\$ \mathrm{r}, 700,000,000$ expended upon scientific research and development during the war period by the three top research agencies (War, Navy and OSRD), more than 80 percent was spent under research and development contracts with private corporations, educational institutions, and nonprofit research organizations. ${ }^{114}$ The private research laboratory, usually an adjunct of an industrial concern, has received the lion's share of the total Federal funds spent on research contracts, a substantial portion of the remainder being paid to academic institutions. ${ }^{115}$

\section{A. Applicable Legal Principles}

In the absence of a statute prescribing the disposition to be made of the patent rights to inventions evolved during the performance of a Government research contract, $^{116}$ the parties are free to agree to any allocation of rights. Since the organizations to which Government contracts are awarded almost always require the employees detailed to the contract to turn over all patent rights in resulting inventions, ${ }^{117}$ the issue becomes essentially whether the contractor or the Government should control the commercial patent rights.

The Government research contract usually contains specific provisions for the allocation of patent rights between the contractor and the Government, but in the relatively rare instances in which the research contract is silent on this score and where no agreement can be implied from the circumstances, ${ }^{118}$ the principles pertinent to the employer-employee relationship would probably be applied by the courts. ${ }^{119}$ Under those principles, the Government would be entitled to the ownership of all inventions made by the contractor or his employee in the course of performing a contract which contemplated invention, and to a nonexclusive royalty-free license if that factor were not present.

${ }^{114}$ See reports cited supra, note 4; and 2 REP. ATT'Y GEN. 243, 326-327, 409.

${ }^{215}$ Report No. 5, supra, note 4, at 74, 298, 310 .

${ }^{218}$ There is apparently no such statute in respect of research contracts, although a Congressional policy may sometimes be derived from a measure such as the Synthetic Liquid Fucls Act of 1944, stppra, note ro, providing for public dedication of patents acquired thereunder.

${ }^{117}$ See 3 REP. ATT'Y GEN. 53-55, 62-66. Government research contracts sometimes contain a representation and agreement by the contractor that he has not made and will not make any arrangement impairing his ability to grant the Government the patent rights called for by the contract. 2 id. at $301,465-466$.

118 Cf. 32 OPS. ATT'Y GEN. 556, 563 (I92I).

${ }^{210}$ See Ordnance Engineering Corp. v. United States, $68 \mathrm{Ct}$ Cl. 301,352 (1929), cert. denied, 302 U. S. 708 (1937); McKinnon Chain Co. v. American Chain Co., 259 Fed. $873,876,878$ (N. D. Pa. r919). Both cases, although dealing with the rights to inventions evolved in the performance of a contract, cited and applied Solomons v. United States, supra, note 9, which dealt solely with patent rights to inventions made by an employee. 


\section{B. The Current Practice}

The several Government agencies which enter into research contracts on a substantial scale fall into three groups in regard to the type of patent provisions inserted in the contract. One group, which usually stipulates for Government ownership or control of inventions resulting from the contract, includes the Rubber Reserve Company and the Defense Plant Corporation, ${ }^{120}$ the Department of the Interior, ${ }^{121}$ the Department of Agriculture, ${ }^{122}$ and the Tennessee Valley Authority. ${ }^{123}$ A second group, which generally leaves the patent rights to the contractor subject only to a nonexclusive, royalty-free license in the Government, consists of the War Department (except the Quartermaster Corps during World War II), ${ }^{124}$ the Navy Department, ${ }^{125}$ the Civil Aeronautics Administration, ${ }^{126}$ and the research branch of the WPB. ${ }^{127}$ The third group, which makes substantial use of both types of patent clauses, includes OSRD, ${ }^{128}$ the National Advisory Committee for Aeronautics, ${ }^{129}$ and

${ }^{120}$ Rubber Reserve Company and Defense Plant Corporation, RFC subsidiaries, usually obtained a free Government license with the right to sublicense others under the inventions resulting from its research contracts. If a private company operating an RFC-owned plant as agent or lessee conducted research at its own expense, the Government acquired a free license running with the plant. 2 REP. ATr'y GeN. 356-373.

${ }_{121}$ The Department of Interior enters into cooperative research arrangements with outside organizations for the pooling of facilities and personnel, and requires either public dedication or Government ownership of inventions made in the course of such projects by employees of either the department or the contractor. If the contractor is a commercial organization, the patents are left to it subject to a free Government license and to the obligation to issue nonexclusive licenses to all applicants at a reasonable royalty. 2 id. at 200-203.

${ }^{122}$ In its grants to State Experiment Stations and land-grant universities to finance experimental and research projects, the Department of Agriculture stipulates for public dedication or Government assignment of resulting inventions, unless the grant is to be expended under the exclusive direction of the grantec, 2 id. at 22-24.

${ }^{223}$ The Tennessee Valley Authority requires an assignment of the patent rights but if the contractor bears part of the cost, the net proceeds of licensing (after payment of $5 \%$ to the inventor) are divided with him. 2 id. at $396-397$.

${ }^{134}$ Of $\mathrm{I} I, 500$ research contracts totalling over half a billion dollars, awarded by the War Department in fiscal years I940-45, only 37 called for an assignment of full title to the Government; all the others left the patents to the contractor subject to a free, nonexclusive license to the Government, sometimes plus a free license under other patents of the contractor covering the article called for by the contract ("reproduction rights"). Regulations promulgated in April, 1945, contemplate a somewhat greater use of the "assignment" clause in special situations. Kilgore Hearings, supra, note 82, at 1089, Ir83; 2 REP. ATT'Y GEN. 455-465, 47x-472 (1947). The Quartermaster Corps and the Ordnance Department have deviated to some extent from the War Department's practice.

${ }^{125}$ The Navy Department almost always has left the patent rights to the contractor, subject to a free Government license, and sometimes plus an option to purchase reproduction rights. Of about $235^{\circ}$ research contracts entered into during the war (all but about Ioo being with commercial concerns), not one seems to have stipulated for the assignment of title to the Government. 2 REP. ATr'Y GEN. 290-295, 301-302.

220 The Civil Acronautics Administration recently recommended to the Secretary of Commerce that the practice be changed to call for assignment of title to the Government. 2 id. at 127-128.

${ }^{227}$ The Office of Production Research and Development of the War Production Board customarily left the patent rights to the contractor subject to a Government license and an option to purchase "reproduction rights." In a few exceptional cases, where research was done upon a basic invention owned by the Government, WPB stipulated for an assignment. 2 id. at 494, 499-502.

${ }^{228}$ The Office of Scientific Research and Development was second only to the War Department in its wartime research expenditures, having spent about half a billion dollars in the period I94I-I946, of which about two-thirds went to academic institutions and one-third to industrial laboratories. In about one-third of all contracts (involving two-thirds of the total expenditures), OSRD required a full assign- 
for a time during World War II included the Quartermaster Corps of the Army. ${ }^{130}$ But taken as a whole, most Government research contracts, involving the major portion of the total dollar amount, leave the commercial patent rights to the contractor. This practice differs from that pursued by private or institutional laboratories, which as a rule grant the financial sponsor the ownership of or an exclusive license under the patent rights. ${ }^{131}$

\section{Policy Considerations}

The issue as to whether the research contractor or the Government should control the patent rights to inventions made in the performance of the contract involves much the same considerations and arguments as those discussed above in connection with the Government employee, but there is one important difference: since the inventor will as a rule retain no rights to his invention, the "incentive to invent" becomes a matter of the acceptability of the terms of the contract to the prospective contractors. Apart from that factor, there seems to be little controversy that the sounder policy is for the Government rather than the contractor to obtain the patent rights under the contract. The view that the technological products of expenditures from the public treasury should inure to the benefit of the public which financed them, and that private interests should not be permitted to exclude the public from the use of such products or to levy a charge for their use, would seem to be equally valid whether the instrumentality employed by the Government to evolve the technology is research contractor or Federal employee. In fact, the representatives of Government, science, and education who urged this view before the Kilgore Subcommittee in 1945 were directing their statements to proposed legislation authorizing Federal aid to scientific research and development by means of "contracts, grants, or other forms of assistance." 132

The specific objections raised against a policy which permits Federal employees to retain commercial patent rights to inventions made in the course of employment are also pertinent, in somewhat modified form, to the research contractor, particularly where the latter is a private company. The contractor who is permitted to profit

ment of patent rights; in all the rest (which included almost all contracts with industrial concerns and about half of those with academic institutions) OSRD left the patent rights to the contractor subject to a free Government license plus an option to purchase "reproduction rights." 2 id. at 330-337; Kilgore Hearings, supra, note 82 , at 1121 .

1202 REP. ATT'Y GEN. 233-234.

${ }^{230}$ For about six months prior to April, 1945, when new regulations were issued by the War Department, the Quartermaster Corps attempted as a matter of policy to include an "assignment" provision in its development contracts, and succeeded in about half of all cascs, being responsible for $\mathrm{I}_{4}$ of the 37 War Department contracts awarded with such a clause during the period 1940-r945. The clause was not used by the Quartermaster Corps if the contractor advanced "cogent objections." The Ordnance Department also used assignment clauses in a few instances for purposes of secrecy where the Government's interest in the inventions was deemed sufficiently acute. 2 id. at $46 \pi-462$.

181 3 REP. ATT'y GEN. 54, 73. Some educational institutions retain the patent rights and grant a free license thereunder to the sponsor. 3 id. at 56 .

${ }^{132}$ S. 1285 , 79th Cong., Ist Sess. (1945) $\$ 2$. This was one of the bills on which the Kilgore Subcommittee held hearings. . See Kilgore Hearings, Pts. I-5, supra, note 82. 
from the Government-financed patents will tend to prefer research projects offering prospects of commercially valuable inventions, and to decline contracts dealing with research in the basic sciences; or, after accepting a contract, he may be led to concentrate the efforts of his staff on "working around" the prior art in an effort to obtain a patentable invention, rather than on the immediate solution of the problem at hand. While collaboration with others may not be as important a factor as in the case of the Federal employee, the contractor will tend to keep his progress secret from others working in the same field, thus discouraging cooperation and pooling of information. And commercial patent rights are as haphazard and unequal a medium of compensation to research contractors as to Federal employees.

Besides the foregoing objections, common to both the research contractor and the Federal employee, those who urge public ownership of technology financed with Federal funds adduce two additional arguments applicable to private contractors:

I. No one would attempt to justify the expenditure of public funds in order to strengthen the position of one private concern in a competitive industry; yet the practice of leaving the patent rights to the contractor, particularly where the latter is an industrial concern, may have that very effect. For this reason Rubber Reserve Company, in all its research and development contracts, reserved the power to throw open resulting inventions to the entire industry on equal terms, lest "private corporations ... enhance their individual patent positions in the synthetic rubber field as an incident to research paid for by the Government." ${ }^{\text {133 }}$ The same point was graphically made at the hearings on the Atomic Energy Act of $194^{134}$ before the special Senate Committee on Atomic Energy, during a discussion of the patent provisions of the bill:

[Senator Millikin of Colorado] Take two big companies. One big company hasn't had this Government business; the other big company has, or the other big company has had the Government business as a result of Government money through the whole operation of our system, coming out with improvements and patents that puts the other big company under somewhat of a disadvantage. The other big company can say, "We paid our share of taxes to put our competitor in the better position he now is in."

The Chairman. [Senator McMahon of Connecticut] And I might also point out, Senator, to further fortify the question, that A company might in the field have been put over to making tanks, where there was no possible peacetime advantage-that is, assuming they both competed in the same line of work-and then B company, which you are talking about that gets this exclusive right has an advantage, and A company would certainly be in a stronger position to complain about it. ${ }^{135}$

The fear was also expressed by the Committee that the retention of patent rights by the contractor in the field of atomic energy research would give him "an unearned privilege" and a head-start in a vitally important new field, with public funds..$^{\mathbf{1 3 6}}$

${ }^{133} 2$ Rep. ATr'y GEN. 362-363.

186 60 Stat. 755, 42 U. S. C. A. \$1801 et seq. (Supp. 1946).

${ }^{135}$ Hearings before Special Senate Committee on Atomic Energy on S. 1717, 79th Cong., 2d Sess. 351 (1946).

130 Id. at $338-358$. 
The Act as passed contained a provision for Government control and licensing of all inventions relating to the field of atomic energy. ${ }^{137}$

2. A second major objection is that retention of patent rights by the industrial contractor may contribute to the ever-increasing concentration of economic and industrial power in fewer and fewer companies, a tendency regarded by many as a serious threat to the survival of our democratic system of free competitive enterprise. The size of the Government's current expenditures for research and the very large share thereof which is paid to private contractors lends special significance to the Government's role. During the five fiscal years r940-1944, one billion dollars of Federal funds, about half of the Government's total research budget, was paid to almost two thousand private companies under contracts for research and development. But fully two-thirds of this billion dollars went to the largest sixty-eight concerns, and more than one-third went to the top ten corporations. Since under all but a minor percentage of these contracts the private contractor retained the commercial patent rights to inventions resulting from the work, the effect of the research contracts was to reenforce the already dominant commercial position of the largest contractors. The great danger of this situation to our system of free enterprise was described by the Smaller War Plants Corporation in a Report to a Senate Committee:

In the long run the concentration of economic power may be greatly strengthened as a result of this centralization of research. The peacetime applications and uses of this scientific knowledge will be enormous. The nature of most scientific research is such that it has a wide variety of practical applications-military as well as peacetime. Obviously the companies in whose laboratories this research work has been carried on will be its chief beneficiaries not only because of their direct acquaintanceship and knowledge of the research but also because of patents. The investigations of the Subcommittee of War Mobilization of the Senate Military Affairs Committee show that over 90 per cent of the contracts made between Government agencies and private industrial laboratories for scientific research and development placed the ownership of patents with the contractor, the Government receiving a royalty-free license for its own use. The research contracts of the War Department, Navy Department, Reconstruction Finance Corporation, and Office of Scientific Research and Development-which accounted for 98 per cent of the Federal funds spent for research in private industrial laboratories-were generally of this nature. The only exception were patents on military items which were considered by the War and Navy Departments to be of a highly strategic character.

This means, in effect, that the large corporations which carried on the great bulk of the federally financed wartime industrial research will have control, through patents, of the commercial applications of that research. ${ }^{138}$

Former Secretary of Commerce Wallace recently expressed the same view to a House subcommittee at hearings on a bill to establish a National Science Foundation with the power to support scientific research. Objecting to a provision of the

\footnotetext{
${ }^{287}$ Section II of the Atomic Energy Act of 1946, 42 U. S. C. A. \$1811 (Supp. 1946).

${ }^{139}$ Economic Concentration and Wordd War II, Report No. 6 of SMaller War Plants Corporatzon to Speciat Senate Commitee to Study Problems of American Small Business, 79th Cong., ad Sess. (1946).
} 
bill which would permit the Foundation to leave patent rights to contractors, the Secretary stated:

They perpetuate and give the approval of the Congress to the past and present unsound policies followed by some Government agencies. The private research contractors of the Foundation will not be small and independent business enterprises; they will be the big corporations with large and well-equipped laboratories which already have a tremendous advantage over their small competitors by virtue of the scientific and technical improvements which they alone can afford to develop and to patent. The provisions of H. R. 6448 will provide Government support and financing to the research and patents of big business and lead to further industrial concentration, lessened competition, and the stifling of small business and new enterprise. ${ }^{130}$

Military authorities and a Senate Committee have noted the desirability of a broad, diversified base in industry and science, with as many units as possible standing ready to serve the nation in time of crisis. ${ }^{140}$ This objective may be hindered by the policy of leaving the patent rights to the private contractor, for the increased concentration of industrial research facilities in a few large industrial corporations means that "the overwhelming majority of American businesses" will lack "adequate access to the benefits of scientific research and advancement." 141 That the free exchange of ideas among many companies operating in the same field will greatly accelerate scientific progress has been dramatically demonstrated by the Government's experience during the war in the fields of penicillin ${ }^{142}$ and synthetic rubber. ${ }^{143}$

The proponents of the policy of permitting contractors to retain the commercial patent rights do not challenge the validity of the foregoing views. ${ }^{144}$ Their position is in effect that the weaknesses and dangers of that policy are the lesser evils, because, according to them, (I) the fullest use and exploitation of an invention is more likely to result under exclusive private control of the patent rights, especially where a substantial investment is required for commercial development; ${ }^{\mathbf{1 4 5}}$ and (2) the best qualified private laboratories would be unwilling to accept Government research contracts which do not leave them the commercial rights to resulting patents. ${ }^{148}$

A simple answer to the first objection would seem to be that if exclusive licenses

${ }^{130}$ Hearings before Public Health Subcommittee of House Committee on Interstate and Foreign Commerce on H. R. 6448, 79th Cong., 2d Sess. 83 (1946).

${ }^{340}$ Subcommittee Report No. 8, National Science Foundation, Report on Science Regulation from Subcommittee on War Mobilization to Senate Committee on Military Affairs, 79th Cong., 2d Sess. 39-40 (1946); 2 REP. ATr'Y GeN. 29r.

141 See Report No. 6, supra, note 138 , at 53 .

1122 REP. ATT'Y GEN. 336-337. $\quad 1432$ id. at $355-356,362-363$.

${ }^{134}$ A Report of the Kilgore Subcommittee in February, 1946, stated that "There was no disagreement with this fundamental principle [that the results of research fully financed by Federal funds should be made publicly available] on the part of any witness who appeared before the Subcommittee or on the part of the thousands of individuals who have expressed interest in the legislation under consideration." See Report No. 8, cited supra, note I40, at II.

${ }^{245}$ See testimony of Dr. Bush of OSRD before Kilgore Subcommittee, Kilgore Hearings, supra, note 82 , at $225-227$.

${ }_{100}$ This view is advanced by spokesmen for the War and Navy Departments and by Dr. Bush of OSRD. Sec 2 Rep. ATr'y GeN. 299, 302, 463; 3 id. 35, 37-38, 206-207, 250, 255, 257, 305-306, 366, 423-424, I050, I090-I09I. 
are in fact necessary and desirable, the Government itself could grant them after obtaining Congressional approval where that is needed. At least that would permit a selection to be made of the inventions whose exploitation requires an exclusive right, so that the remainder could be thrown open to the public. Moreover, the Government could attach conditions to its grant of exclusive licenses in order to guard against suppression or misuse of the inventions.

Apart from this, however, the objection that Government ownership inhibits the fullest exploitation of the invention is not borne out by actual experience. Opinion within the Government has been divided as to the necessity or desirability of issuing exclusive licenses under Government-owned inventions in order to stimulate their fullest exploitation by private capital, ${ }^{14 \tau}$ but the experience in the Government would indicate that a policy of nonexclusive licensing is for the most part sufficient to bring inventions into general use. During the period 1942-1945, the Office of the Alien Property Custodian offered to grant royalty-free, nonexclusive licenses under some 22,000 inventions seized from the enemy, and actually issued about $I, 800$ licenses to almost $\mathrm{I}, 000$ licensees under approximately $\mathrm{I} \mathrm{I}, 000$ patents and applications. During the same three-year period the Custodian also offered to grant exclusive licenses for limited periods to applicants who could demonstrate that exclusive rights are necessary for fullest exploitation of the technology. Only seven applicants filed preliminary requests for exclusive licenses, alleged to be necessary in order to recoup "development costs," but none of these ever filed a final application for an exclusive license or made the requisite showing of need for such a license. Some of these seven applicants were in fact content with nonexclusive licenses. The Custodian recently reported that his policy of nonexclusive licensing has been eminently successful, and that a large number of improvements upon the licensed inventions have resulted from their manufacture and use by many concerns rather than by a single licensee. ${ }^{148}$

This experience is matched by that of the Research Corporation and the Chemical Foundation, two large nonprofit organizations engaged in the exploitation of inventions, which have found that a policy of nonexclusive licensing is successful in bringing their inventions into general commercial use. ${ }^{149}$

The point of view of the American scientist on this issue is exemplified by the

${ }^{247}$ That it is necessary in some cases has been the view of some officials of the Department of Agriculture. Kilgore Hearings, supra, note 82, at 729-730; 2 REP. ATT'Y Ges. 35-36; and of Dr. Bush of OSRD, Kilgore Hearings, supra, note 82, at 225-227. That it would be necessary only in exceptional cases was the opinion of officials within the War Department, 2 REP. ATr'y GEN. 479-483, Interior De. partment, 2 id. at 207-208, and the Bureau of Standards, 2 id. at 131. That it is neither necessary not desirable was the belief of Commissioner of Patents Ooms, Secretary of the Interior Ickes, Secretary of Commerce Wallace, Kilgore Hearings, supra, note 82 , at $140,340,698$, and several officials in the Department of Agriculture, 2 RER. ATT'Y GEN. 3I-36.

${ }^{248}$ Kilgore Hearings, supra, note 82 , at $675-678,681-685,688$. This experience is particularly significant since the Custodian is one of the few Government agencies with the power to issue exclusive licenses.

${ }^{240} 3$ ReP. ATt'y GEN. 9, 12, 54. Most universities issue only nonexclusive licenses under their patents. 3 id. at 57 . 
testimony before the Kilgore Subcommittee of Dean Gray of the University of Illinois Graduate School:

There is no convincing evidence in support of the contention that new discoveries would remain unutilized if patent rights were held by the Federal Government and made freely available to all. All we have on this point is the allegation of certain monopolistically minded groups that they would not care to develop new discoveries on such a basis. But our economic history indicates clearly that where competition with respect to new developments has prevailed American businessmen have been quick to take advantage of such opportunities. I know of no quicker or surer way to stimulate production, provide employment, and raise the standard of living than for the Federal Government to use its great power and resources to unlock the treasures of modern science and to make them available to all on equal terms. ${ }^{150}$

It is significant that apparently no representative of American industry has argued for exclusive licenses under Government-owned patents; on the contrary, the industry spokesmen before Congressional committees have unanimously advocated free public dedication not only because those discoveries were "acquired at the expense, through taxes, of citizens of the United States,"151 but also because "the private-enterprise system will best be preserved if all Government-owned patents . . . are thrown open to the entire public without governmental regulation or restriction."152

Industry's objection to any policy other than public dedication or nonexclusive licensing of Government-owned inventions is basically due to the desire to avoid the regulation and policing likely to be a concomitant of licensing. ${ }^{153}$ Another objection lies in the difficulties of selecting the recipient of the exclusive licenses without favoritism or discrimination; for if the traditional technique of competitive bidding is used, it would inevitably favor the larger and wealthier bidders..$^{154}$

Moreover, Government authorities have pointed out that there are other means to encourage and stimulate commercial exploitation of Government technology. Publicity, demonstration projects, and other promotional devices have been used with good results by the Alien Property Custodian. ${ }^{155}$ Another tested device is for the Government to finance or subsidize the pilot-plant or experimental stages of the manufacture or use of the invention, thus lessening the private financial risk involved in pioneer production. This procedure has been found preferable to exclusive licensing by the Tennessee Valley Authority ${ }^{156}$ and other Government agencies. ${ }^{157}$

${ }^{100}$ Kilgore Hearings, supra, note 82 , at $29 \mathrm{I}-292$.

${ }^{152}$ Testimony of Chairman of Committee on Patents and Research of the National Association of Manufacturers at Hearings before the House Patents Committee on H. R. 5842 and H. R. 5940, 79th Cong., 2d Sess. 3-4 (1946). To the same effect, see statement of same witness, Kilgore Hearings, supra, note 82 , at $18 \mathrm{r}$.

${ }_{152}$ Testimony before Kilgore Subcommittee of the Vice-president in charge of development, Standard Oil Company of Indiana, Kilgore Hearings, supra, note 82, at 419,425 . See also the testimony in behalf of the American Patent Law Association, id. at II88.

${ }^{163}$ Kilgore Hearings, supra, note 82 , at $177-178,419,425$.

206 This point has been made by Col. Lippincott of the War Department, 2 REP. ATT'Y GEN. 481-482, and by the Alien Property Custodian, Kilgore Hearings, supra, note 82, at 681-682.

${ }^{105} 2$ Rep. ATT'Y GEN. 67-68; Kilgore Hearings, supra, note 82, at $677,685,688$.

${ }^{150} 2$ REP. ATT'Y GEN. 399.

${ }^{267}$ Such as subsidiary corporations of R. F. C., 2 id. at 356 , and the Office of Production Research and Development of the War Production Board, 2 id. at 493. 
The remaining and the most serious objection against any change in the current policy of leaving commercial patent rights to the contractor is advanced by spokesmen for the Armed Services and for industry. That objection is that the best organizations, particularly among industrial laboratories, will decline to accept Government research work unless left with the patent rights, or will quote much higher prices for the research to compensate for the denial of patent rights. ${ }^{168}$ Proponents of this view assert that the difficulties will be even more pronounced where the contractor has already made independent progress towards the solution of the problem, so that turning over the resulting patents means giving the Government, gratis, the fruits of the contractor's earlier independent efforts. ${ }^{159}$

At the outset, it may be noted that the argument is restricted to industrial laboratories, for under current practice most of the academic and other nonprofit research organizations either leave the patent rights to the financial sponsor of the research project or else dedicate the inventions to the public. ${ }^{100}$ For example, OSRD reserved all patent rights under research contracts totalling over $\$ 325,000,000$, awarded principally to academic institutions, and representing about one-third of all OSRD contracts. ${ }^{161}$ And as applied to the industrial laboratory, there is a very meager basis upon which to test the validity of the argument in the light of actual experience.

The meagerness of evidence stems from the fact that during the recent decade, when the research contract began to be used on a large scale, the predominant practice in the Government was to leave the patent rights to private industry. The three Federal agencies which spent about 95 per cent of all Government research funds during World War II (the War and Navy Departments and OSRD) as a matter of policy left the patents to the private contractor, stipulating for Government ownership in only a small percentage of all cases. ${ }^{162}$ Nevertheless, such evidence as there is indicates that the percentage of patents assigned to the Government would have been considerably greater if the affirmative policy of Government had been to require assignments, and that most eligible research organizations would not refuse research contracts guaranteeing them a reasonable profit on their work, particularly if a uniform policy of Government precluded more favorable terms from another agency. For example, during World War II the War Department reserved title to resulting patents in less than I per cent of all its research contracts and the Navy Department in practically none; ${ }^{163}$ yet the Quartermaster Corps, when it adopted and affirmatively enforced an opposite policy, succeeded in obtaining a title stipulation in almost half of all its research contracts. ${ }^{184}$ The Rubber Reserve Company has

${ }^{168} 2$ id. at $299,302,463 ; 3$ id. at $250,305-306$.

${ }^{150} 3$ id. at $35,37-38,206-207,255,257,366,423-424,1050,1090-1091$.

1003 id. at $53-56,73$.

162 See notes $124,125,128$, stpra.

1032 REP. ATT'Y GEN. 302, 458-460, 463-465; Kilgore Hearings, supra, note 82, at 1089, 1183.

104 2 ReP. ATT'Y GeN. 462. The Ordnance Department was also successful in obtaining such stipulations where it considered secrecy necessary or for other reasons. $2 i d$. at $46 \mathrm{r}$. This was at a time when more favorable terms were available from the Navy Department and from all other branches of the War Department. The Armed Services usually paid the research contractor sufficient to cover costs, overhead and a reasonable profit, and also left him the commercial patent rights. 2 id. at $460 ;$ sce Kilgore Hearings, stspra, note 82, at 255-257. 
been uniformly successful during the war in sponsoring research in the synthetic rubber field, under contracts which gave the Government the power to throw open the resulting inventions to the entire industry. ${ }^{165}$

Another relevant bit of experience comes from the atomic energy field. The early research contracts awarded under the Manhattan District's atomic energy project left the patent rights to the contractors subject only to a Government license, but in the late spring of 1942 President Roosevelt directed Dr. Bush of OSRD "to arrange as far as possible for the vesting in the Government of the title to patents on inventions and discoveries made on the project." At the Government's request virtually all contractors agreed to retroactive revision of their contracts to provide for Government ownership of the inventions, including some upon which patent applications had already been filed, and thenceforth all research contracts dealing with the project reserved to the Government full power over patent rights. ${ }^{166}$ Other agencies which reserve title to the patent rights as a matter of policy seem to have had no difficulty in obtaining qualified organizations to carry on the desired research. ${ }^{167}$

The inference seems reasonable that American industry has obtained the commercial patent rights under most of its research contracts with the Government because that has been the policy of the three largest research agencies; that the policy of reserving the patent rights to the Government should prove equally effective if affirmatively put into practice throughout the Government; and that American industry would not refuse to make its facilities available to the Government on a basis which guarantees it against risk of loss and assures it a reasonable profit.

The situation may, of course, arise where the most experienced organization in the field has already made considerable progress towards solution of the technical problem posed by the Government research contract, so that the organization may refuse to take on the work unless its prior contribution is recognized by the award of all resulting patents. ${ }^{168}$ Perhaps the soundest manner of dealing with such situations would be to find the second best organization; for the progress already made by the first company and the investment involved will ordinarily be sufficient to guarantee continuance of the work to completion. To finance another company's efforts in the field may have the multifold advantage of stimulating the first concern to even greater efforts, of adding independent thought and facilities to solution of the problem, and of broadening the research experience in the industry. ${ }^{109}$ But if

${ }^{106} 2$ ReP. ATT'Y GeN. 356, 374-375.

${ }^{100}$ Hearings before Special Senate Committee on Atomic Energy on S. 17x7, 79th Cong., 2d Sess. 332-334, 338, 34x, 352 (1946). Secretary Patterson told a House Committee shortly thereafter that the War Department had acquired "virtually all" of the inventions and patents existing in the atomic energy field. Hearings before the Hotse Committee on Military Affairs on S. 1777, 79th Cong., 2d Sess. $45(1946)$.

${ }_{107}$ Agriculture, 2 REP. ATT'Y GEN. 22-24; Interior, 2 id. at 200-203; TVA, 2 id. at 396-397; National Advisory Committce for Aeronautics, 2 id. at 233-234.

${ }^{108}$ This point was made before the Kilgore Subcommittee by representatives of the War and Navy Departments and by Dr. Bush of OSRD. See Kilgore Hearings, supra, note 82, at 249-251, 254-256.

${ }^{200}$ Dr. Philip R. White of the Rockefeller Institute for Medical Research told the Kilgore Sub- 
an emergency precludes this alternative, there is available the procedure embodied in the Kilgore bill ${ }^{170}$ and recommended by the Attorney General in his report: ${ }^{171}$ the patent rights could be left to the contractor subject to a Government license, and with appropriate safeguards to protect the public against suppression or unreasonable use of the inventions to which public funds contributed.

The proponents of the present policy warn that to reserve patent rights to the Government would increase appreciably the cost of Government research. ${ }^{172}$ The actual experience contradicts this view. For instance, the half billion dollars' worth of research contracts awarded by OSRD during the period 1940-1945 repaid the contractor his actual costs plus a percentage of the direct labor costs as an overhead allowance (roo per cent of the direct labor costs for industrial contractors, and $5^{\circ}$ per cent for institutional contractors). This basis was the same whether the Government or the contractor obtained the commercial patent rights. Moreover, OSRD reserved title in about half the contracts with institutions; yet the compensation formula was not only the same as that used in the other institutional contracts which gave the patents to the contractors, but was less than that embodied in the industrial contracts which also gave the patents to the contractors. ${ }^{173}$ Likewise, the research and development contracts financed by Rubber Reserve Company and by Defense Plant Corporation, which gave the Government the right to throw open the resulting inventions to the entire industry, were awarded on the same payment basis as the contracts of other RFC subsidiaries calling only for a nonexclusive Government license. ${ }^{174}$

The uniformity of compensation regardless of the type of patent stipulation may be attributable to the difficulty of evaluating future inventions. The prudent businessman, because of the unknown factors involved in the commercial success of an invention not yet produced, must place a very low or a purely nominal valuation upon it, and the practice in industrial laboratories bears this out. ${ }^{175}$ The indications from experience are therefore that the disposition of patent rights under a research contract will not have an appreciable effect upon the compensation the contractor will expect to receive. But even if some greater cost should result, the question may well be asked whether it would not be wiser to pay that increase out of the general

committee that if a policy of public ownership would tend to discourage participation in Federal research by the large industrial concerns, "This will be all to the good since such concerns do not need Government support, and small businesses and the general public stand only to gain from a rigorous patent policy." Id. at 604 .

${ }_{170}$ Id. at 10.

171 I REP. ATT'y GeN. xog-rio.

${ }^{172}$ Kilgore Hearings, supra, note 82, at 206-207, 255-257; 2 REP. ATT'Y GEN. 303, 338-339.

1732 ReP. ATT'Y GEN. 330-336.

2742 id. at $374-376$.

${ }^{175}$ Dr. Bush, before the Kilgore Subcommittee, characterized any cvaluation of future patent rights as an attempt to "force negotiation on a very intangible basis." Kilgore Hearings, supra, note 82, at $20 \%$. Industrial laboratories, which require their technical and research employees to assign all patent rights to the company, usually, pay no extra compensation on that account; those that do, pay a very nominal amount. Id. at II87; 3 REP. ATT'Y GEN. 242, 246-247. 
public funds, rather than to save it by enabling the contractor to levy a royalty upon the use of the invention, or even to deny its use to the public in order to protect his stake in older processes.

Essentially for the above reasons the Attorney General, in his May, 1947, Report to the President, recommended the establishment of a Government-wide policy requiring that contracts for research and development work financed with Federal funds should reserve to the United States all rights to inventions produced in the performance of the contract, except in emergencies; and that where an emergency requires an exception to this basic policy because of inability to find a qualified organization willing to take on the contract with the basic patent stipulation, the contract may leave to the contractor the commercial rights in inventions to which he has already made a substantial independent contribution, subject to a royaltyfree, nonexclusive license to the Government, and also subject to the obligation on the part of the contractor (or his assignee) to place the inventions in adequate commercial use within a designated period. ${ }^{176}$ The Attorney General also recommended that, as a basic policy, all Government-owned inventions be made fully available to the public without charge, by public dedication or royalty-free, nonexclusive licensing. ${ }^{177}$

\section{IV}

\section{Conclusion}

The policy which should be followed in regard to the control of patentable inventions produced in the course of Government-financed research is one of major current importance in both economic and social terms. The three-year investigation upon which the Attorney General based his report and recommendations is unquestionably the most exhaustive and comprehensive yet made, and although the past forty years have been marked by a series of unsuccessful attempts to evolve a sound uniform Government policy, there is some ground for the belief that the latest effort will prove more effective. Whether or not the policy recommended by the Attorney General is adopted throughout the Government, the attention focused upon the problems may at least encourage a trial of the policy by enough Government agencies to furnish a fair test of its wisdom.

${ }_{178}^{178}$ ReP. ATT'Y GEN. rog-rxo.

${ }^{177}$ I id. at 130-13I. 